\title{
The Role of Growth Factors in Intestinal Regeneration and Repair in Necrotizing Enterocolitis
}

\author{
Kathryn J. Rowland, M.D., Pamela M. Choi, M.D., and Brad W. Warner, M.D. \\ Division of Pediatric Surgery, St Louis Children's Hospital, Department of Surgery, Washington \\ University School of Medicine, St Louis, MO 63110, USA
}

\begin{abstract}
Necrotizing enterocolitis (NEC) is a devastating intestinal disease resulting in major neonatal morbidity and mortality. The pathology is poorly understood, and means of preventing and treating NEC are limited. Several endogenous growth factors have been identified as having important roles in intestinal growth as well as aiding intestinal repair from injury or inflammation. In this review, we will discuss several growth factors as mediators of intestinal regeneration and repair as well as potential therapeutic agents for NEC.
\end{abstract}

\section{Keywords}

necrotizing enterocolitis; epidermal growth factor; insulin-like growth factor; hepatocyte growth factor; glucagon-like peptide-2; growth hormone

\section{INTRODUCTION}

Necrotizing enterocolitis (NEC) is the most common gastrointestinal emergency encountered in the neonatal period. ${ }^{1}$ The exact pathogenesis of NEC is unknown and likely multifactorial. Prematurity, aberrant bacterial colonization, hypoxia, and intestinal ischemia have all been implicated. ${ }^{2}$ Localized intestinal mucosal injury is thought to result in an amplified cycle of bacterial invasion, immune activation, uncontrolled inflammation, and gut barrier failure, leading to necrosis, perforation, sepsis, and shock..$^{2-4}$

In the dynamic milieu of the developing gut, growth factors play a critical role in intestinal development. Growth factors have also been established to be important mediators of gastrointestinal repair, with roles in cellular proliferation, differentiation, migration, and survival. ${ }^{5-8}$ It is logical to consider that absent or reduced levels of specific factors that are normally expressed during later periods of gestation may contribute to the development of NEC. As such, exogenous replacement of these key factor(s) may be of clinical value in the prevention and treatment of NEC. ${ }^{9}$ Epidermal growth factor (EGF), heparin-binding epidermal-like growth factor (HB-EGF), growth hormone (GH), insulin-like growth factor (IGF), glucagon-like peptide 2 (GLP-2), keratinocyte growth factor (KGF), hepatocyte growth factor (HGF), granulocyte colony stimulating factor (G-CSF), erythropoietin (Epo),

\footnotetext{
(c) 2013 Elsevier Inc. All rights reserved.

*Correspondence: Brad W. Warner, M.D. St. Louis Children's Hospital One Children's Place; Suite 5S40 St. Louis MO 63110 (314) 454-6022 - Phone (314) 454-2442 - Fax brad.warner@wustl.edu.

Publisher's Disclaimer: This is a PDF file of an unedited manuscript that has been accepted for publication. As a service to our customers we are providing this early version of the manuscript. The manuscript will undergo copyediting, typesetting, and review of the resulting proof before it is published in its final citable form. Please note that during the production process errors may be discovered which could affect the content, and all legal disclaimers that apply to the journal pertain.
} 
and intestinal trefoil factor (ITF) have all been implicated in the pathogenesis and prevention of NEC, and will be the focus of the present review (the effects of these growth factors is summarized in Table 1).

\section{EPIDERMAL GROWTH FACTOR}

EGF and Normal Intestinal Development-EGF is a 53-amino acid peptide, established as a major trophic factor for the developing intestine. ${ }^{10-13}$ EGF is normally found in fluids that bathe the developing intestine, including amniotic fluid, fetal urine, breast milk, bile, and saliva. ${ }^{14}$ As gestation progresses, the concentration of EGF in amniotic fluid increases. ${ }^{13,15}$ In rabbits, exogenous in utero infusion of EGF stimulates intestinal growth and accelerates maturation of intestinal enzyme activity. ${ }^{16}$ Maternal colostrum and milk are the main sources of intestinal EGF in the postnatal period. EGF is resistant to proteolytic degradation across a range of gastric $\mathrm{pH}$ and as development progresses the vast majority of EGF is produced in the salivary glands, with minor contributions from the duodenal Bruner's glands, ulcer associated cell lineage, and the kidney. ${ }^{17-20}$

Pharmacological stimulation of submandibular gland EGF secretion results in small intestine trophic effects. ${ }^{21}$

Under basal conditions, EGF signaling is crucial for intestinal epithelial cell proliferation and survival. ${ }^{22}$ The EGF receptor (EGFR) has tyrosine kinase activity and is localized primarily on the basolateral surface of the enterocytes, however, apical EGFR activity has been observed. ${ }^{23-30}$ Recent work from our laboratory has shown that the proliferative effects of EGF are preserved despite loss of the enterocyte EGFR, suggesting that EGFR activity in the underlying submucosa and muscularis layers of the bowel may also play a role. ${ }^{31}$ The importance of EGF in gut development is highlighted by the fact that global EGFR deletion is associated with embryonic lethality. ${ }^{32}$ Mice with global EGFR deletion that do survive to delivery die early in the neonatal period with a hemorrhagic enteritis that resembles NEC in humans. ${ }^{32}$

EGF and Gastrointestinal Repair-The mucosal lining of the gastrointestinal tract consists of a single layer of columnar epithelial cells responsible for providing a barrier between the toxic luminal contents of the intestine and the subepithelial structures. Epithelial injury results in restitution, a process by which cells flatten and adopt a squamoid appearance to seal the wound, followed by epithelial proliferation and epithelial maturation and differentiation. ${ }^{33,34}$ EGF has established healing effects on the gastrointestinal mucosa following injury. ${ }^{17,35}$ Ulceration of the gastrointestinal epithelium induces expression of ulcer associated cell lineage, which has been shown to secrete EGF on the ulcer margin, contributing to ulcer repair. ${ }^{36}$ The expression of EGFR protein is increased at the margin of mucosal ulcers, with a 75-fold increase in the number of cells expressing EGFR observed in a rat model of acetic acid-induced ulceration. ${ }^{37}$

Reduced EGF levels have been associated with mucosal ulcer disease. Low salivary EGF levels have been recorded in patients with active duodenal ulcer disease. ${ }^{38}$ Similarly, immunoreactive EGF levels in gastric juice and saliva are reduced in patients with gastric ulcers. ${ }^{39,40}$ Furthermore, pentagastrin stimulation of salivary and gastric EGF secretion is impaired in patients with active Helicobacter pylori and duodenal ulcer disease. ${ }^{41}$ For these patients, lack of EGF may set the stage for decreased mucosal resistance to stress and/or impaired ability for repair in the face of mucosal injury.

EGF supplementation has been demonstrated to improve mucosal repair and regeneration in several conditions. In a pig model, EGF has been shown to significantly reduce esophageal ulceration, stricture formation, and mucosal histological damage associated with sclerotherapy. ${ }^{42}$ In rats with gastric ulcers, orogastric EGF given in combination with 
sucralfate improved ulcer healing. ${ }^{43}$ A small study of humans treated with intravenous EGF demonstrated superior gastric ulcer healing with EGF as compared to antiulcer cetraxate hydrochloride treatment. ${ }^{43}$ Oral EGF administration in patients with duodenal ulcer disease resulted in comparable success to treatment with cimetidine. ${ }^{44}$ In a rat model of gluteninduced enteropathy, EGF supplementation has been shown to protect the intestine from the pathological changes associated with interferon-gamma and gliadin administration. ${ }^{45}$ Similarly, acetic acid injury of the colon in rats was attenuated with administration of exogenous EGF. ${ }^{46}$ EGF supplementation has been shown to prevent intestinal mucosal atrophy associated with elemental and parenteral nutrition. ${ }^{47,48,49}$ Human randomized controlled trials of EGF enemas for patients with left-sided ulcerative colitis demonstrated EGF to be superior to placebo in regards to disease activity, sigmoidoscopic findings, and histologic grading of injury. ${ }^{50}$

Our laboratory has established a critical role for EGF in the process of intestinal adaptation following massive small bowel resection (SBR). Adaptation is a compensatory response, characterized by significant increases in villus height, crypt depth, and enterocyte proliferation, and resulting in increased absorptive mucosal surface area, allowing for adequate absorption of enteral nutrition despite significant loss of bowel length. ${ }^{51}$ Following SBR, salivary EGF levels are significantly increased with greater expression and activation of intestinal EGFR within the crypts and muscularis layer of the intestine. ${ }^{52,53}$ Systemic EGF stimulation enhances adaptation. EGF given exogenously after SBR or overexpressed in transgenic mice results in a magnified adaptation response. ${ }^{54-56}$ Perturbed EGFR activity inhibits the adaptation response. Removal of the major endogenous source of EGF via sialoadenectomy attenuates adaptation, an effect that is partially reversible with either systemic or oral administration of EGF. ${ }^{57}$ Further, resection-induced adaptation after SBR is inhibited by systemic administration of EGFR inhibitors and in mutant mice (waved-2) that have generalized perturbed EGFR activity. ${ }^{58,59}$ These studies highlight the essential role of EGF in physiologic intestinal repair.

EGF and NEC-Several lines of evidence indicate an important role for EGF in the pathogenesis of NEC. Global EGFR deficiency in mice results in embryonic or early neonatal lethality with a hemorrhagic enteritis resembling human NEC. ${ }^{32}$ Waved-2 mice with deficient EGFR expression demonstrate increased susceptibility to agents associated with intestinal damage, such as dextran sodium sulfate. ${ }^{60}$ In experimental NEC models, EGF has been shown to contribute to the pathogenesis of NEC. In a neonatal rat model of NEC, Dvorak and colleagues demonstrated significantly increased EGFR mRNA expression within the ileum of affected animals. Immunohistochemistry localized the EGFR expression to the epithelium, corresponding with the site of maximal injury. Enteral EGF supplementation prior to injury significantly decreased both the incidence and severity of NEC, as well as diminished EGFR expression. ${ }^{61}$

Increased intestinal permeability has been implicated in the pathogenesis of NEC. ${ }^{2-4,62,63}$ During the early postnatal period, greater intestinal permeability allows for immunoglobulin and growth factor absorption from the colostrum and milk. ${ }^{64}$ However, insults to the immature intestinal barrier can result in mucosal damage, barrier failure, and initiation of inflammation. ${ }^{65}$ Under normal conditions, the enterocyte is protected from the luminal contents by mucin-secreting goblet cells. A primary deficiency in the mucous layer may therefore result in intestinal injury. Studies of animal NEC models have demonstrated a decrease in the total number of goblet cells. ${ }^{63}$ EGF supplementation is known to increase goblet cell density in short gut syndrome, while inhibition of the EGFR decreases goblet cell density. ${ }^{66}$ In a neonatal rat model of NEC, treatment with EGF accelerated goblet cell maturation and mucin production and normalized the expression of tight junction proteins, restoring the intestinal barrier and resulting in prevention of NEC. ${ }^{63}$ In addition, EGF plays 
an important role in enterocyte migration and restitution following mucosal injury. EGF has been shown to enhance enterocyte migration and stimulate mucosal restitution in rat stomach and human colon. ${ }^{67-69}$

Another important component in the pathogenesis of NEC is a perturbation of the normal cellular barrier to bacteria and/or bacterial products. ${ }^{70,71}$ Prematurity is associated with limited gastrointestinal defenses, exposure to antibiotics, and feeding practices which contribute to the colonization of the gastrointestinal tract with select species of virulent bacteria. In addition, compared to mature animals, immature animals have been demonstrated to have greater adherence and translocation of pathogenic bacteria. ${ }^{70} \mathrm{EGF}$ may play a role in maintaining the intestinal barrier and preventing bacterial translocation. Supplementation of exogenous EGF to formula-fed newborn rabbits, burn injured mice, and rats receiving total parenteral nutrition has been shown to decrease bacterial translocation. ${ }^{48,72,73}$

Dysregulated inflammation and immune system activation have been implicated in NEC development. ${ }^{4,74,75}$ Neonatal rat models of NEC have demonstrated elevated expression of pro-inflammatory IL-18 and IL-12, with increasing concentrations correlating with the degree of tissue damage. ${ }^{76}$ Patients with NEC have elevated levels of pro-inflammatory mediators such as platelet activating factor, tumor necrosis factor-alpha, IL-8, and nitric oxide, as well as enhanced expression of anti-inflammatory cytokines, such as IL-10. ${ }^{77-79}$ Interestingly, IL-10 deficient mice are known to spontaneously develop enterocolitis. ${ }^{80}$ Exogenous EGF administration in a neonatal rat NEC model attenuated the expression of IL-18 (a pro-inflammatory mediator) and increased production of IL-10 (an antiinflammatory cytokine) in the ileum. ${ }^{81}$

Enterocyte apoptosis has been shown to precede gross morphological changes in neonatal rat models of NEC. ${ }^{82}$ Administration of pan-caspase inhibitors reduced the incidence of both apoptosis and NEC. ${ }^{82}$ Pro-apoptotic Bax mRNA levels have been shown to be markedly elevated following the induction of NEC in neonatal rat models, with antiapoptotic Bcl-2 mRNA levels markedly reduced. EGF supplementation in this model decreased proapoptotic Bax levels and increased antiapoptotic Bcl-2 mRNA levels. ${ }^{83}$ In addition, increased autophagy has been demonstrated in the intestinal epithelium of NEC patients and in the ileum of NEC rats. In in-vivo and in-vitro models, EGF has been shown to inhibit intestinal autophagy. ${ }^{84}$ These studies suggest that alterations in the balance of cell survival and death may provide a mechanism by which EGF maintains intestinal integrity and protects the epithelium against NEC.

In humans, an association between EGF production and NEC has been reported. Serum and salivary EGF levels are decreased in patients with NEC requiring surgical intervention as compared to age-matched controls without NEC. ${ }^{85,86}$ A study of urinary EGF revealed an increase from baseline in neonate urinary EGF levels, normalized to creatinine, at the time of NEC diagnosis. ${ }^{87}$ No change from baseline was seen in neonates without NEC. ${ }^{87}$ Urinary levels of EGF indicate that EGF production increases with gestational age. ${ }^{88-90}$

Given that the single most important risk factor for development of NEC is prematurity, a prospective cohort study demonstrated that salivary EGF levels are directly related to gestational age using both uni- and multivariate regression models. ${ }^{9}$ In this study, infants who developed NEC had lower initial EGF levels and demonstrated a greater increase in EGF between the first and second weeks of life than those infants who did not develop NEC. ${ }^{9}$

Human infants who receive breast milk are less likely to develop NEC than those infants feed formula. ${ }^{91,92}$ In a neonatal rat model of NEC, breast milk supplementation reduced the 
severity of injury as compared to formula fed controls. ${ }^{93}$ EGF is one of the major peptides present in biologically significant concentrations in human colostrum and milk, but is absent from all commercially available infant formulas. ${ }^{94-96}$ The concentration of EGF in maternal milk is inversely proportional to gestational age. ${ }^{97}$ Notably, the greater the degree of prematurity, and therefore the greater risk of NEC, the higher the concentration of EGF present in breast milk. This illustrates a remarkable compensatory response to removal of the fetus from the EGF-rich amniotic fluid, and may explain, at least in part, that the protective effect of human milk against development of NEC.

In humans, the clinical use of EGF for treatment on NEC has been limited. A single case report of an 8 month old critically ill infant with unsalvageable intestinal necrosis treated with 4 day intravenous EGF infusion survived with full recovery of the intestine. ${ }^{98} \mathrm{~A}$ small, randomized, prospective trial of intravenous recombinant EGF versus placebo control in premature infants with evidence of NEC demonstrated improved mucosal thickness and crypt surface area on rectal biopsy with recombinant EGF. A significant limitation of this study was the extrapolation of changes in the distal colon to that of the upper intestine. Changes in the distal colon reflect those of the upper intestine in animal models; however this has not been tested in humans. Importantly, no significant toxicities were reported with EGF administration. ${ }^{99}$ The trophic effects of EGF are clear and further studies are warranted to test the possibility that EGF supplementation may prevent the development of NEC.

\section{HEPARIN-BINDING EPIDERMAL-LIKE GROWTH FACTOR}

HB-EGF is a 22-kDa glycoprotein that is a member of the EGF family and signals via the EGFR pathway to stimulate cellular growth and differentiation. ${ }^{100}$ Unlike other members of the EGF family, HB-EGF is unique in its ability to bind strongly to heparin. ${ }^{101}$ Like EGF, HB-EGF is found in biologically significant quantities in amniotic fluid and human milk. ${ }^{102}$ HB-EGF expression has been demonstrated to be elevated in response to tissue damage, hypoxia, stress, and during wound healing and regeneration. ${ }^{103-105}$ In humans, intestinal tissue obtained at the time of operative intervention for NEC demonstrated higher HB-EGF mRNA expression at the healthy resection margin as compared to tissue adjacent to frankly necrotic tissue, raising the possibility that HB-EGF expression deficiency contributes to the pathogenesis of NEC or, alternatively, that HB-EGF overexpression at the healthy tissue margin promotes healing in response to tissue injury. ${ }^{106}$

While at low endogenous basal levels in normal cells, HB-EGF may represent an immediate early response gene to hypoxia and stress. ${ }^{106,107}$ Intestinal ischemia results in tissue damage and reperfusion of ischemic intestinal tissues leads to a burst in free radical formation, causing further tissue injury. The Besner laboratory has established a protective role for HBEGF in the intestinal ischemia/reperfusion response. HB-EGF expression increases after in vitro intestinal epithelial cells anoxia/reoxygenation injury and after intestinal ischemia/ reperfusion injury. ${ }^{108}$ In rats, HB-EGF supplementation enhanced and accelerated enterocyte restitution following intestinal ischemia/reperfusion injury. This early response to injury was inhibited with blocking of the EGFR. ${ }^{109} \mathrm{HB}-\mathrm{EGF}$ has been demonstrated to preserve crypt cell proliferation and epithelial cell integrity, and decrease bacterial translocation following ischemia/reperfusion injury. ${ }^{110}$ Similarly, HB-EGF protects intestinal stem cells from hypoxic injury and promotes intestinal stem cell activation and survival. ${ }^{111}$ Work from other laboratories suggests that HB-EGF is also implicated in regulating cell proliferation and apoptosis in response to ischemia/reperfusion injury. ${ }^{112}$

Ischemia is implicated as a contributing factor to the pathogenesis of NEC and the protective effects of HB-EGF have been seen following intestinal ischemia/reperfusion injury in animal models of NEC. ${ }^{106}$ A neonatal rat model of NEC demonstrated a higher incidence of NEC in animals exposed to hypothermia, hypoxia, hypertonic feedings plus 
lipopolysaccharide as compared to breast milk. Administration of HB-EGF in this model reduced the incidence and severity of NEC, and extended survival rate and survival time. ${ }^{106}$ HB-EGF supplementation increased enterocyte restitution and proliferation, decreased intestinal permeability, and reduced rates of apoptosis. ${ }^{113-115}$ As well, HB-EGF resulted in preservation of microvascular blood flow. ${ }^{116}$ Overexpression of HB-EGF in mice results in decreased intestinal permeability and a decreased incidence of experimental NEC, effects that are inhibited with administration of a HB-EGF antagonist. ${ }^{17}$ Mice deficient in HBEGF have significantly increased intestinal permeability and a higher incidence of experimental NEC, findings that are reversed with administration of exogenous HB-EGF. ${ }^{118}$ Recently, the Besner laboratory has demonstrated that HB-EGF acts synergistically with administered mesenchymal stem cells (MSC) in a newborn rat model of NEC. Rat pups who received both HB-EGF and MSC had decreased incidence of NEC, decreased intestinal permeability, and increased survival compared to rats who received HB-EGF or MSC alone. ${ }^{119}$

Both HB-EGF and EGF have been demonstrated to reduce the incidence of NEC in neonatal rat models, however, EGF has been shown to provide better protection at physiological doses, while HB-EGF protection requires pharmacological dosing. ${ }^{120}$ HB-EGF production in a Pichia pastoris yeast system has been reported in preparation for human clinical trials. $^{121}$

\section{GLUCAGON-LIKE PEPTIDE 2}

GLP-2 is a 33-amino acid peptide that regulates a wide range of actions on the intestine including growth, motility, nutrients, and blood flow. It is secreted from enteroendocrine L cells of the distal small intestine and colon in response to enteral nutrients, particularly fatty acids and glucose. ${ }^{122,123}$

The full mechanism of GLP2 is not well understood. The GLP-2 receptor is a G-protein coupled receptor that is expressed in greatest concentration in the proximal bowel and decreases distally. ${ }^{124}$ The receptor is localized to intestinal enteroendocrine cells, enteric neurons, and subepithelial myofibroblasts. ${ }^{125-129}$ However, the GLP-2 receptor is not found in crypt or villus enterocytes, suggesting that the GLP-2 requires downstream intermediaries to carry out its effects. ${ }^{130}$ Earlier research has shown that the trophic effects of GLP-2 required the activation of enteric neurons. ${ }^{127}$ In rat models of colitis, the anti-inflammatory effects of GLP-2 administration were abolished when a VIP antagonist was added.

Additionally, immunohistochemical staining found GLP-2 activated VIP expressing neurons in the submucosa. This suggests that VIP is an important downstream mediator of GLP-2 initiated anti-inflammatory effects. ${ }^{131}$ However, exogenous administration to VIP knockout mice continued to demonstrate enhanced proliferation and bowel growth, indicating that VIP does not play a role in GLP-2 driven growth. ${ }^{130}$

Another indirect mediator of the intestinal actions of GLP-2 is IGF-1, an enterotrophic factor that will be discussed later. IGF-1 was found to be required for GLP-2 induced small intestine growth as these effects were negated in IGF-1 knockout mice. ${ }^{132}$ Inducible deletion of the IGF-1 receptor has also been shown to abrogate any trophic effects of GLP-2. ${ }^{133}$ Exogenous GLP-2 administration increases IGF1 mRNA levels in intestinal cells of rats and mice, and it has been found that GLP-2 may activate the subepithelial myofibroblasts to release IGF-1 via the PI3K/AKT pathway. ${ }^{134-136}$

While the exact role of GLP-2 in neonatal intestinal development remains unknown, it has been theorized that GLP-2 may have an important role in the ontogeny of the gut. The GLP-2 precursor, proglucagon, and prohormone convertase, the enzyme responsible for cleaving proglucagon into GLP-2, are both found in the intestine of rat fetuses. ${ }^{137}$ GLP-2R 
mRNA levels are significantly higher in the intestine of fetal/neonatal rats than in adult rats. ${ }^{138,139}$ Premature piglets are more responsive than neonatal piglets to exogenous GLP-2, demonstrating greater increases in the activity of BBM enzymes. ${ }^{140}$ Similarly, more premature infants had greater levels of GLP-2 at baseline as well as a greater GLP-2 response after enteral feeding than infants born closer to term. ${ }^{141}$

The more immediate effects of GLP-2 involve slowing proximal motility as well as decreasing gastric emptying. ${ }^{142}$ However, over the long term, GLP-2 is an intestinotrophic factor and has been found to stimulate crypt cell proliferation, decrease epithelial apoptosis, enhance barrier function ${ }^{143-145}$ as well as increase the activity of brush border enzymes. ${ }^{139,140}$ Adult mice given subcutaneous injections of GLP-2 had increased small intestine weight and villus/crypt morphology. ${ }^{146,147}$ Piglets also had dose-dependent increases in intestinal weight, DNA/protein content, villus height, and decreased crypt/villus apoptosis with increased cell survival and proliferation. ${ }^{148}$

Several studies have found that GLP-2 is an important regulator of nutrient absorption. ${ }^{139,149}$ Cheeseman and Tsang found that rats given intravenous GLP-2 were found to have increased glucose uptake as well as increased SGLT-1 protein. ${ }^{149,150}$ Similarly, other studies have found increased rates of fructose absorption with increased GLUT2 expression as well as increased SGLT1. ${ }^{151}$ GLP-2 has also been implicated in increasing mesenteric blood flow. ${ }^{152}$ TPN-fed piglets given intravascular infusions of GLP-2 demonstrated increased portal drained visceral blood glow, increased intestinal blood flow volume, as well as increased nitric oxide synthase activity. ${ }^{153}$

While there are no specific publications regarding the use of GLP-2 in the context of NEC, there have been many studies with GLP-2 that have demonstrated its intestinal protective effects. GLP-2 has been beneficial in inflammatory bowel disease and is associated with increasing rates of remission and ability to taper steroids. ${ }^{154}$ Mice with DSS-induced colitis given exogenous GLP2 also demonstrated preserved mucosal integrity, increased intestinal mass, and increased proliferation. ${ }^{155}$ Increased proliferation and decreased apoptosis were seen in mice with indomethacin-induced enteritis. ${ }^{156}$

GLP-2 is also believed to play an important role in resection-induced adaptation responses, as levels are increased immediately after resection. ${ }^{157}$ Subcutaneous GLP-2 administration in rats after small bowel resection led to increases in mucosal mass. ${ }^{158}$ Enhanced adaptation was also seen in GLP-2 treated rats after resection in the absence of enteral nutrition. ${ }^{159}$ In infants with short bowel syndrome, GLP-2 levels correlated with length of remnant bowel as the shortened intestines had very low GLP-2 levels. Additionally, higher GLP-2 levels also correlated with the ability to better tolerate enteral feeding. ${ }^{160}$ The ability of infants to wean from of TPN corresponded with higher GLP-2 levels. ${ }^{160,161}$ Patients with intestinal failure treated with GLP-2 have also demonstrated improved nutrient absorption and increased body weight. 162

GLP-2 has also been found to attenuate intestinal injury in necrotizing pancreatitis ${ }^{145}$, burns $^{163}$, and ischemia-reperfusion injuries. ${ }^{129,164,165}$ Mice given GLP-2 demonstrated enhanced barrier function ${ }^{144,166}$ as well as decreased bacterial translocation. ${ }^{156}$ Given its wide protective effects, GLP-2 may be a promising adjunct to the prevention or therapy of NEC.

\section{GROWTH HORMONE}

Growth Hormone $(\mathrm{GH})$ is a $22 \mathrm{kDA}$ anabolic protein that is synthesized in the anterior pituitary and released into the systemic circulation with multiple tissue targets. $\mathrm{GH}$ has a significant role in postnatal growth as well as lipid and carbohydrate metabolism. ${ }^{167,168}$ 
The GH receptor is a type 1 cytokine receptor that signals tyrosine kinase JAK2 pathways. GH receptors are expressed throughout the small and large intestine in the muscularis propria, submucosa, muscularis mucosa, lamina propria, and epithelial layers. ${ }^{169}$ The widespread presence of GH receptors in the intestine suggests a direct effect of GH on growth. ${ }^{170}$ In addition to direct stimulation on intestinal growth, the downstream effects of GH include the activation of STAT transcription factors leading to increased expression of IGF-1. Another intestinotrophic growth factor, IGF-1 is believed to be an important mediator for $\mathrm{GH}$ in the intestine. ${ }^{171,172}$

The enterotrophic effects of GH have been demonstrated in transgenic mice with overexpression of GH. ${ }^{173}$ Similarly, rats given GH with glutamine and/or high protein diet after small bowel resection demonstrated increased villus height/crypt death, positive nitrogen balance, and bowel growth. ${ }^{174,175}$

The potential benefits of GH in NEC have not been well established. One prospective study found that neonates who had surgery for NEC or gastroschisis and were randomized to receive GH had improved lipid utilization. ${ }^{176}$ However, GH has been shown to enhance intestinal repair in various inflammatory states. When exposed to DSS-induced colitis, these mice also had increased survival, decreased inflammation, and increased crypt cell proliferation. ${ }^{177}$ These same effects were seen in mice exposed to TNBS-induced colitis. ${ }^{178}$ In the pediatric population, a randomized control trial studied the effects of patients with Crohn's disease who were treated with corticosteroids and GH or corticosteroids alone. While no differences in mucosal healing were seen by endoscopic evaluation, the GH group was found to have higher rates of clinical remission. The GH group also received the added benefit of increased linear growth. GH was well tolerated without any notable deleterious side effects. ${ }^{179}$

Work in the laboratory has shown signs that GH enhances adaptation after small bowel resection, yielding mucosal hyperplasia, increased absorption, as well as increased length. ${ }^{180,181} \mathrm{GH}$ has also yielded modest results in clinical trials with SBS patients. TPN dependent patients with SBS given recombinant GH were subsequently found to have increased absorption of nitrogen, carbohydrates, and fat. ${ }^{182}$ Other studies have found SBS patients to have increased absorption when GH was given with glutamine and a high protein, low-fat diet. ${ }^{183,184}$ However, a randomized open-label study in TPN dependent children with SBS found that GH did not improve weaning off TPN. ${ }^{185}$

\section{INSULIN-LIKE GROWTH FACTOR-1}

IGF-1 is a small 70 amino acid polypeptide synthesized primarily in the liver but also in the gastrointestinal tract. IGF-1 is found in the fetal intestine and in human milk, suggesting a role in intestinal development. ${ }^{186-188}$ The IGF-1 Receptor (IGF-1R) is a transmembrane tyrosine kinase receptor with structural homology to insulin receptors. Activation of IGF-1R leads to autophosphorylation and activation of signaling cascades such as IRS-1/PI3K/AKT and GRB2/Ras/ERK pathways. ${ }^{189}$ IGF-1 is regulated by GH, insulin, and caloric intake. ${ }^{190}$

IGF-1 increases intestinal cell proliferation and increases intestinal growth..$^{7,8,191-195}$ It is a key mediator of other trophic factors, namely GH and GLP-2. ${ }^{132-136,171,172,196}$ When oral IGF-1 was given to piglets, increased nutrient absorption, mucosal growth, intestinal weight, protein and DNA was observed. ${ }^{197,198}$

IGF-1 can also demonstrate protective effects during inflammation and cytokine driven apoptosis. ${ }^{199-201}$ IGF-1 expression is increased in the intestine in animal models of IBD and in patient's with Crohn's. ${ }^{195}$ In animal models of sepsis as well as in human patients, 
decreased levels of IGF-1 correlate with increased bacterial translation. Further, exogenous IGF1 administration in mice was associated with decreased rates of translocation. ${ }^{202}$

Oxidative stress activates the cellular protective phosphatidylinositol 3-kinase (PI3-K) pathway. Additionally, activation of this pathway can be enhanced by exogenous IGF-1 administration during NEC and promotes cell survival. ${ }^{203-205}$ Premature neonates with persistently low levels of serum IGF-1 were found to be at increased risk of NEC. ${ }^{206}$

Baregamian et al. found that intestinal IGF-1R expression was elevated in vivo in a mouse pup model of NEC as well as in vitro rat and fetal human intestinal cell lines exposed to oxidative stress. Additionally, increased IGF-1R phosphorylation was observed in model intestinal epithelial cells while inhibition of IGF-1R lead to increased cellular apoptosis. ${ }^{207}$ Another study using a hypoxia/reoxygenation model for NEC in mice found that IGF-1 administration resulted in attenuated intestinal injury with decreased necrosis and decreased apoptotic indexes. ${ }^{208}$

\section{GRANULOCYTE COLONY STIMULATING FACTOR}

G-CSF is an 18.8-kDa glycoprotein involved in the regulation of neutrophil production. Neutrophils are key players in the human inflammatory and immune response, dysregulation of which has been implicated in the pathogenesis on NEC. G-CSF is found in amniotic fluid and human milk in physiologically significant concentrations. ${ }^{209-211}$ Consistent with the increased risk of NEC in premature infants, the concentration of G-CSF in cord blood of term infants is higher than that of preterm infants, and although concentrations in preterm infants increased under conditions of perinatal stress or infection, the increase in concentration was not to the degree observed in term infants. ${ }^{212} \mathrm{G}$-CSF receptors are expressed on both neutrophils and nonhematopoietic cells, including fetal and neonate enterocytes. ${ }^{210-213}$ Following mucosal injury a differential immune response is seen in adult and neonatal murine models of colitis, with neutrophil infiltration to the intestine seen in adult models of enterocolitis, and macrophage infiltration to the intestine in neonatal models. ${ }^{214}$ Depletion of neutrophils has been shown to exacerbate NEC in animal models. ${ }^{215}$

G-CSF has been established to be protective to the intestinal epithelium. In rats treated with the chemotherapeutic agent Paclitaxel addition of G-CSF resulted in decreased villus atrophy and enterocyte apoptosis, and decreased intestinal bacterial translocation. ${ }^{216}$ In a rat NEC model, administration of G-CSF prevented mucosal injury. ${ }^{217} \mathrm{~A}$ small pilot study of enteral G-CSF administered to preterm infants with stage I NEC reported shorter time to resolution of clinical and radiological signs of disease and prevention of disease progression following G-CSF treatment as compared to placebo controls. ${ }^{218}$

\section{ERYTHROPOIETIN}

Epo is a 30.4-kDa glycoprotein, secreted by the fetal liver and adult kidney in response to anemia. ${ }^{219}$ In addition to stimulating erythropoiesis, Epo has been implicated in immunologic modulation, anti-inflammatory effects, improved wound healing, and reduction in hypoxia induced apoptosis. ${ }^{220}$ Epo is present in amniotic fluid and breast milk. ${ }^{221-226}$ Functional Epo receptors are present in fetal and postnatal small bowel. ${ }^{227,228}$ Fetal human enterocytes have been shown to decrease secretion of pro-inflammatory IL-8 in vitro in response to Epo, perhaps offering a protective effect in the setting of NEC. ${ }^{229}$ In a rat hypoxia NEC model, pretreatment with intraperitoneal Epo limited mucosal injury and resulted in decreased levels of the proinflammatory mediator nitric oxide. ${ }^{230}$ Oral Epo supplementation has also been shown in rat models to protect intestinal barrier function and reduce the incidence of NEC. ${ }^{231}$ A retrospective cohort study of very low birth weight 
infants given recombinant Epo for prevention or treatment of anemia demonstrated that the incidence of NEC was lower in those infants who received recombinant Epo. ${ }^{232}$

\section{INTESTINAL TREFOIL FACTOR}

The trefoil factor family (TFF) is a group of 7- to 14-kd polypeptides that are secreted by mucus producing epithelial cells, predominantly in the gastrointestinal tract. Three mammalian TFF members have been identified; TTF1 expressed by surface and pit mucus cells in the stomach, TTF2 expressed by mucus neck and glandular mucus cells of the stomach and Brunner's glands of the proximal duodenum, and TTF3 (also known as ITF) expressed by goblet cells of the intestine and colon. ${ }^{233}$ Trefoil peptides are established to be enterocyte protective and promote healing in response to gastrointestinal damage. Trefoil peptide expression is upregulated in ulcerative conditions such as peptic ulcer disease and inflammatory bowel disease. ${ }^{234-237}$ ITF promotes epithelial cell migration and inhibits apoptosis. ${ }^{238,239}$ TTF2 supplementation has been shown to protect the intestinal epithelium in rat models of colitis. ${ }^{240}$ ITF administration has been shown to prevent and heal injury from acute DSS-induced colitis and well as radiation and chemotherapy induced intestinal mucositis. ${ }^{241,242}$ ITF deficiency in mice is associated with extreme sensitivity to mucosal injury and failure to undergo mucosal repair. ${ }^{243}$ ITF has been demonstrated to be relatively deficient in premature rats, suggesting a possible role in the development on NEC in premature infants. ${ }^{244}$ Administration of ITF in a rat model of NEC reduced the severity of intestinal injury. 245

\section{KERATINOCYTE GROWTH FACTOR}

KGF is a member of the fibroblast growth factor family and stimulates growth and differentiation of epithelial cells. ${ }^{246}$ Exogenous KGF supplementation in rats results in epithelial cell proliferation and induction of mucin-producing goblet cells. ${ }^{247} \mathrm{KGF}$ and its receptor are present in the human fetal gastrointestinal tract and in vitro stimulation of human fetal enterocytes with KGF results in cellular proliferation. ${ }^{248}$ Expression of KGF is increased in surgical patients with inflammatory bowel disease and correlates with the degree of intestinal inflammation. ${ }^{249}$ In animal models of colitis, KGF administration reduces the extent of mucosal injury. ${ }^{250}$ KGF gene therapy in rats ameliorated acid-induced ulcerative colitis. ${ }^{251} \mathrm{KGF}$ supplementation decreases total parenteral nutrition related enterocyte apoptosis and results in increased expression of the antiapoptotic Bcl-2 protein. ${ }^{252}$ In animal models of radiation and chemotherapy intestinal injury, KGF pretreatment increased enterocyte survival and mucosal thickness. ${ }^{253,254}$ Deficiency of KGF in mice is associated with severe colonic inflammation and delayed tissue repair in dextran sodium sulfate induced colitis. ${ }^{255}$ Recombinant KGF treatment has been studied in ulcerative colitis patients. In human phase II studies, recombinant KGF failed to induce remission in ulcerative colitis patients, however the maximal treatment dose may have been targeted too low for a beneficial effect to be seen. Importantly, no significant adverse effects of KGF treatment as compared to placebo were observed. ${ }^{256}$ While the intestinal protective effects of KGF are established, the role of KGF in NEC is currently unknown.

\section{HEPATOCYTE GROWTH FACTOR}

HGF is $94 \mathrm{kDa}$ glycoprotein that regulates cellular proliferation, survival, and angiogenesis in many different cells through MET receptor tyrosine kinase. ${ }^{257,258}$ It is present in breast milk as well as in fetal intestinal tissue. ${ }^{259,260}$ HGF is secreted by mesenchymal cells in an inactive form and is subsequently activated by HGF activator (HGFA), which is synthesized primarily in the liver and to a lesser extent in the intestine. ${ }^{261,262}$

HGF plays an active role in the repair of injured intestinal tissue, ${ }^{262-266}$ - however the mechanism is poorly understood. In response to tissue injury myofibroblasts, platelets, and 
neutrophils were all found to release HGF which then interacts with receptors on the basolateral membrane of epithelial cells. ${ }^{267-269}$ HGF-deficient mice are embryonically lethal ${ }^{270,271}$, while HGFA-deficient mice are born without any apparent abnormalities. However when exposed to DSS or acetic acid, HGFA-deficient mice experience increased mortality with impaired regeneration of injured colonic mucosa. ${ }^{272}$

After intestinal resection, HGF has been shown to increase epithelial proliferation as well as increase protein concentration and mucosal DNA content. ${ }^{273,274}$ In animal model of burns, HGF treatment leads to increased intestinal proliferation and preserved villus structures. ${ }^{275}$ Rats with DSS-induced colitis given intraperitoneal administration also had decreased weight loss, increased epithelial regeneration, and increased cellular proliferation. ${ }^{276}$ Rats with TNBS-induced colitis given intravenous HGF also demonstrated decreased ulcer coverage and increased epithelial proliferation. ${ }^{277}$

HGF inhibits intestinal epithelial apoptosis after ischemic reperfusion injury. ${ }^{278}$ Meldrum et al. used a NEC model with fetal small intestine epithelial cells that were exposed to hypoxic injury. These cells were then cultivated in mesenchymal stem cell-conditioned media and were found to have enhanced viability and proliferation with the supernatants from the cellular media to have increased levels of IL-6, VEGF, and HGF. This suggests that mesenchymal stem cells may release these factors in a paracrine manner to enhance cellular survival. ${ }^{279}$ However, transgenic mice who over-express HGF were found to have an increase in benign and malignant liver and mammary gland tumors. ${ }^{280-283}$ Thus, further research is needed to assess the safety of HGF as potential therapeutic agents in humans.

\section{CONCLUSION}

Growth factors play an important role in both the development of the gastrointestinal tract and the response to injury. These factors play important roles as mediators of cellular proliferation, migration, differentiation, and survival. In both the fetal and postnatal environment, the developing intestine is exposed to EGF, HB-EGF, GH, IGF, GLP-2, GCSF, Epo, ITF, KGF, and HGF through luminal exposure to amniotic fluid and human milk. While the exact pathogenesis of NEC is unknown, the trophic and protective effects of growth factors in the intestine are clear. Recent evidence suggests that such factors may act synergistically to prevent intestinal injury. ${ }^{13,119,183,284-288}$ Further studies are warranted to test the possibility that supplementation of various factor(s) may prevent the development of this devastating disease.

\section{REFERENCES}

1. Kosloske AM. Epidemiology of necrotizing enterocolitis. Acta Paediatr Suppl. 1994; 396:2-7. [PubMed: 8086675]

2. Neu J, Walker WA. Necrotizing enterocolitis. N Engl J Med. 2011; 364:255-264. [PubMed: 21247316]

3. Israel EJ. Neonatal necrotizing enterocolitis, a disease of the immature intestinal mucosal barrier. Acta Paediatr Suppl. 1994; 396:27-32. [PubMed: 8086678]

4. Petrosyan M, Guner YS, Williams M, et al. Current concepts regarding the pathogenesis of necrotizing enterocolitis. Pediatr Surg Int. 2009; 25:309-318. [PubMed: 19301015]

5. Dominguez JA, Coopersmith CM. Can we protect the gut in critical illness? The role of growth factors and other novel approaches. Crit Care Clin. 2010; 26:549-65. [PubMed: 20643306]

6. Krishnan K, Arnone B, Buchman A. Intestinal growth factors: potential use in the treatment of inflammatory bowel disease and their role in mucosal healing. Inflamm Bowel Dis. 2011; 17:410422. [PubMed: 20848489]

7. Drozdowski L, Thomson AB. Intestinal hormones and growth factors: effects on the small intestine. World J Gastroenterol. 2009; 15:385-406. [PubMed: 19152442] 
8. McMellen ME, Wakeman D, Longshore SW, et al. Growth factors: possible roles for clinical management of the short bowel syndrome. Semin Pediatr Surg. 2010; 19:35-43. [PubMed: 20123272]

9. Warner BB, Ryan AL, Seeger K, et al. Ontogeny of salivary epidermal growth factor and necrotizing enterocolitis. J Pediatr. 2007; 150:358-363. [PubMed: 17382110]

10. Duh G, Mouri N, Warburton D, et al. EGF regulates early embryonic mouse gut development in chemically defined organ culture. Pediatr Res. 2000; 48:794-802. [PubMed: 11102549]

11. Carver JD, Barness LA. Trophic factors for the gastrointestinal tract. Clin Perinatol. 1996; 23:265285. [PubMed: 8780905]

12. Campbell ID, Baron M, Cooke RM, et al. Structure-function relationships in epidermal growth factor (EGF) and transforming growth factor-alpha (TGF-alpha). Biochem Pharmacol. 1990; 40:35-40. [PubMed: 2372309]

13. Hirai C, Ichiba H, Saito M, et al. Trophic effect of multiple growth factors in amniotic fluid or human milk on cultured human fetal small intestinal cells. J Pediatr Gastroenterol Nutr. 2002; 34:524-528. [PubMed: 12050579]

14. Carpenter G. Epidermal growth factor is a major growth-promoting agent in human milk. Science. 1980; 210:198-199. [PubMed: 6968093]

15. Scott SM, Buenaflor GG, Orth DN. Immunoreactive human epidermal growth factor concentrations in amniotic fluid, umbilical artery and vein serum, and placenta in full-term and preterm infants. Biol Neonate. 1989; 56:246-251. [PubMed: 2605277]

16. Buchmiller TL, Shaw KS, Chopourian HL, et al. Effect of transamniotic administration of epidermal growth factor on fetal rabbit small intestinal nutrient transport and disaccharidase development. J Pediatr Surg. 1993; 28:1239-1244. [PubMed: 8263680]

17. Playford RJ, Wright NA. Why is epidermal growth factor present in the gut lumen? Gut. 1996; 38:303-305. [PubMed: 8675078]

18. Barnard JA, Beauchamp RD, Russell WE, et al. Epidermal growth factor-related peptides and their relevance to gastrointestinal pathophysiology. Gastroenterology. 1995; 108:564-580. [PubMed: 7835600]

19. Heitz PU, Kasper M, van NS, et al. Immunohistochemical localisation of urogastrone to human duodenal and submandibular glands. Gut. 1978; 19:408-413. [PubMed: 350728]

20. Britton JR, George-Nascimento C, Udall JN, et al. Minimal hydrolysis of epidermal growth factor by gastric fluid of preterm infants. Gut. 1989; 30:327-332. [PubMed: 2785073]

21. Li AK, Schattenkerk ME, Huffman RG, et al. Hypersecretion of submandibular saliva in male mice: trophic response in small intestine. Gastroenterology. 1983; 84:949-955. [PubMed: 6187621]

22. Abud HE, Watson N, Heath JK. Growth of intestinal epithelium in organ culture is dependent on EGF signalling. Exp Cell Res. 2005; 303:252-262. [PubMed: 15652340]

23. Orsini B, Calabro A, Milani S, et al. Localization of epidermal growth factor/transforming growth factor-alpha receptor in the human gastric mucosa. An immunohistochemical and in situ hybridization study. Virchows Arch A Pathol Anat Histopathol. 1993; 423:57-63. [PubMed: 8212535]

24. Mynott CL, Pinches SA, Garner A, et al. Location and characteristics of epidermal growth factor binding to enterocyte plasma membranes. Biochem Soc Trans. 1991; 19:307S. [PubMed: 1783144]

25. Playford RJ, Hanby AM, Gschmeissner S, et al. The epidermal growth factor receptor (EGF-R) is present on the basolateral, but not the apical, surface of enterocytes in the human gastrointestinal tract. Gut. 1996; 39:262-266. [PubMed: 8977341]

26. Scheving LA, Shiurba RA, Nguyen TD, et al. Epidermal growth factor receptor of the intestinal enterocyte. Localization to laterobasal but not brush border membrane. J Biol Chem. 1989; 264:1735-1741. [PubMed: 2912982]

27. Thompson JF, van den BM, Stokkers PC. Developmental regulation of epidermal growth factor receptor kinase in rat intestine. Gastroenterology. 1994; 107:1278-1287. [PubMed: 7926492] 
28. Kelly D, McFadyen M, King TP, et al. Characterization and autoradiographic localization of the epidermal growth factor receptor in the jejunum of neonatal and weaned pigs. Reprod Fertil Dev. 1992; 4:183-191. [PubMed: 1438948]

29. Menard D, Pothier P. Radioautographic localization of epidermal growth factor receptors in human fetal gut. Gastroenterology. 1991; 101:640-649. [PubMed: 1860628]

30. Thompson JF. Specific receptors for epidermal growth factor in rat intestinal microvillus membranes. Am J Physiol. 1988; 254:G429-G435. [PubMed: 3348408]

31. Rowland KJ, McMellen ME, Wakeman D, et al. Enterocyte expression of epidermal growth factor receptor is not required for intestinal adaptation in response to massive small bowel resection. $\mathrm{J}$ Pediatr Surg. 2012; 47:1748-1753. [PubMed: 22974617]

32. Miettinen PJ, Berger JE, Meneses J, et al. Epithelial immaturity and multiorgan failure in mice lacking epidermal growth factor receptor. Nature. 1995; 376:337-341. [PubMed: 7630400]

33. Moore R, Carlson S, Madara JL. Rapid barrier restitution in an in vitro model of intestinal epithelial injury. Lab Invest. 1989; 60:237-244. [PubMed: 2915518]

34. Nusrat A, Delp C, Madara JL. Intestinal epithelial restitution. Characterization of a cell culture model and mapping of cytoskeletal elements in migrating cells. J Clin Invest. 1992; 89:15011511. [PubMed: 1569187]

35. Jones MK, Tomikawa M, Mohajer B, et al. Gastrointestinal mucosal regeneration: role of growth factors. Front Biosci. 1999; 4:D303-D309. [PubMed: 10077540]

36. Wright NA, Pike C, Elia G. Induction of a novel epidermal growth factor-secreting cell lineage by mucosal ulceration in human gastrointestinal stem cells. Nature. 1990; 343:82-85. [PubMed: 2296294]

37. Tarnawski A, Stachura J, Durbin T, et al. Increased expression of epidermal growth factor receptor during gastric ulcer healing in rats. Gastroenterology. 1992; 102:695-698. [PubMed: 1732139]

38. Ohmura E, Emoto N, Tsushima T, et al. Salivary immunoreactive human epidermal growth factor (IR-hEGF) in patients with peptic ulcer disease. Hepatogastroenterology. 1987; 34:160-163. [PubMed: 3499370]

39. Calabro A, Orsini B, Brocchi A, et al. Gastric juice immunoreactive epidermal growth factor levels in patients with peptic ulcer disease. Am J Gastroenterol. 1990; 85:404-407. [PubMed: 2327382]

40. Hansen G, Muller C, Sinha P, et al. Gastric ulcer is accompanied by a decrease of epidermal growth factor in gastric juice and saliva. J Clin Chem Clin Biochem. 1989; 27:539-545. [PubMed: 2607319]

41. Konturek PC, Ernst H, Konturek J, et al. Salivary and gastric luminal release of epidermal growth factor under basal conditions and after pentagastrin stimulation in healthy subjects and in duodenal ulcer patients before and after eradication of Helicobacter pylori. J Physiol Pharmacol. 1996; 47:187-194. [PubMed: 8777298]

42. Juhl CO, Jensen LS, Steiniche T, et al. Recombinant human epidermal growth factor prevents sclerotherapy-induced esophageal ulcer and stricture formations in pigs. Dig Dis Sci. 1994; 39:393-401. [PubMed: 8313824]

43. Itoh M, Matsuo Y. Gastric ulcer treatment with intravenous human epidermal growth factor: a double-blind controlled clinical study. J Gastroenterol Hepatol. 1994; 9(Suppl 1):S78-S83. [PubMed: 7881024]

44. Haedo W, Gonzalez T, Mas JA, et al. Oral human recombinant epidermal growth factor in the treatment of patients with duodenal ulcer. Rev Esp Enferm Dig. 1996; 88:409-418. [PubMed: 8755321]

45. Stepankova R, Kofronova O, Tuckova L, et al. Experimentally induced gluten enteropathy and protective effect of epidermal growth factor in artificially fed neonatal rats. J Pediatr Gastroenterol Nutr. 2003; 36:96-104. [PubMed: 12500003]

46. Ribbons KA, Howarth GS, Ford WD, et al. Effects of epidermal growth factor administration on repair of acetic acid-induced colonic ulcerations in rats. Growth Factors. 1997; 14:89-101. [PubMed: 9255602]

47. Sasaki M, FitzGerald AJ, Mandir N, et al. Keratinocyte growth factor and epidermal growth factor can reverse the intestinal atrophy associated with elemental diets in mice. Exp Physiol. 2003; 88:261-267. [PubMed: 12621531] 
48. McAndrew HF, Lloyd DA, Rintala R, et al. The effects of intravenous epidermal growth factor on bacterial translocation and central venous catheter infection in the rat total parenteral nutrition model. Pediatr Surg Int. 2000; 16:169-173. [PubMed: 10786974]

49. Tsujikawa T, Bamba T, Hosoda S. The trophic effect of epidermal growth factor on morphological changes and polyamine metabolism in the small intestine of rats. Gastroenterol Jpn. 1990; 25:328334. [PubMed: 2358163]

50. Sinha A, Nightingale J, West KP, et al. Epidermal growth factor enemas with oral mesalamine for mild-to-moderate left-sided ulcerative colitis or proctitis. N Engl J Med. 2003; 349:350-357. [PubMed: 12878742]

51. Helmrath MA, VanderKolk WE, Can G, et al. Intestinal adaptation following massive small bowel resection in the mouse. J Am Coll Surg. 1996; 183:441-449. [PubMed: 8912612]

52. Shin CE, Falcone RA Jr. Duane KR, et al. The distribution of endogenous epidermal growth factor after small bowel resection suggests increased intestinal utilization during adaptation. J Pediatr Surg. 1999; 34:22-26. [PubMed: 10022137]

53. Knott AW, Erwin CR, Profitt SA, et al. Localization of postresection EGF receptor expression using laser capture microdissection. J Pediatr Surg. 2003; 38:440-445. [PubMed: 12632364]

54. Chaet MS, Arya G, Ziegler MM, et al. Epidermal growth factor enhances intestinal adaptation after massive small bowel resection. J Pediatr Surg. 1994; 29:1035-1038. [PubMed: 7965502]

55. Shin CE, Helmrath MA, Falcone RA Jr. et al. Epidermal growth factor augments adaptation following small bowel resection: optimal dosage, route, and timing of administration. J Surg Res. 1998; 77:11-16. [PubMed: 9698525]

56. Erwin CR, Helmrath MA, Shin CE, et al. Intestinal overexpression of EGF in transgenic mice enhances adaptation after small bowel resection. Am J Physiol. 1999; 277:G533-G540. [PubMed: 10484377]

57. Helmrath MA, Shin CE, Fox JW, et al. Adaptation after small bowel resection is attenuated by sialoadenectomy: the role for endogenous epidermal growth factor. Surgery. 1998; 124:848-854. [PubMed: 9823398]

58. O'Brien DP, Nelson LA, Williams JL, et al. Selective inhibition of the epidermal growth factor receptor impairs intestinal adaptation after small bowel resection. J Surg Res. 2002; 105:25-30. [PubMed: 12069497]

59. Helmrath MA, Erwin CR, Warner BW. A defective EGF-receptor in waved-2 mice attenuates intestinal adaptation. J Surg Res. 1997; 69:76-80. [PubMed: 9202650]

60. Egger B, Buchler MW, Lakshmanan J, et al. Mice harboring a defective epidermal growth factor receptor (waved-2) have an increased susceptibility to acute dextran sulfate-induced colitis. Scand J Gastroenterol. 2000; 35:1181-1187. [PubMed: 11145290]

61. Dvorak B, Halpern MD, Holubec H, et al. Epidermal growth factor reduces the development of necrotizing enterocolitis in a neonatal rat model. Am J Physiol Gastrointest Liver Physiol. 2002; 282:G156-G164. [PubMed: 11751169]

62. Piena-Spoel M, Albers MJ, ten KJ, et al. Intestinal permeability in newborns with necrotizing enterocolitis and controls: Does the sugar absorption test provide guidelines for the time to (re-)introduce enteral nutrition? J Pediatr Surg. 2001; 36:587-592. [PubMed: 11283883]

63. Clark JA, Doelle SM, Halpern MD, et al. Intestinal barrier failure during experimental necrotizing enterocolitis: protective effect of EGF treatment. Am J Physiol Gastrointest Liver Physiol. 2006; 291:G938-G949. [PubMed: 16798726]

64. Pacha J. Development of intestinal transport function in mammals. Physiol Rev. 2000; 80:16331667. [PubMed: 11015621]

65. Rouwet EV, Heineman E, Buurman WA, et al. Intestinal permeability and carrier-mediated monosaccharide absorption in preterm neonates during the early postnatal period. Pediatr Res. 2002; 51:64-70. [PubMed: 11756641]

66. Jarboe MD, Juno RJ, Stehr W, et al. Epidermal growth factor receptor signaling regulates goblet cell production after small bowel resection. J Pediatr Surg. 2005; 40:92-97. [PubMed: 15868565]

67. Miller CA, Debas HT. Epidermal growth factor stimulates the restitution of rat gastric mucosa in vitro. Exp Physiol. 1995; 80:1009-1018. [PubMed: 8962701] 
68. Riegler M, Sedivy R, Sogukoglu T, et al. Effect of growth factors on epithelial restitution of human colonic mucosa in vitro. Scand J Gastroenterol. 1997; 32:925-932. [PubMed: 9299673]

69. Basson MD, Modlin IM, Madri JA. Human enterocyte (Caco-2) migration is modulated in vitro by extracellular matrix composition and epidermal growth factor. J Clin Invest. 1992; 90:15-23. [PubMed: 1634605]

70. Claud EC, Walker WA. Hypothesis: inappropriate colonization of the premature intestine can cause neonatal necrotizing enterocolitis. FASEB J. 2001; 15:1398-1403. [PubMed: 11387237]

71. Walker WA. Role of nutrients and bacterial colonization in the development of intestinal host defense. J Pediatr Gastroenterol Nutr. 2000; 30(Suppl 2):S2-S7. [PubMed: 10749395]

72. Okuyama H, Urao M, Lee D, et al. The effect of epidermal growth factor on bacterial translocation in newborn rabbits. J Pediatr Surg. 1998; 33:225-228. [PubMed: 9498391]

73. Zapata-Sirvent RL, Hansbrough JF, Wolf P, et al. Epidermal growth factor limits structural alterations in gastrointestinal tissues and decreases bacterial translocation in burned mice. Surgery. 1993; 113:564-573. [PubMed: 8488477]

74. Nanthakumar NN, Fusunyan RD, Sanderson I, et al. Inflammation in the developing human intestine: A possible pathophysiologic contribution to necrotizing enterocolitis. Proc Natl Acad Sci U S A. 2000; 97:6043-6048. [PubMed: 10823949]

75. Caplan MS, Jilling T. New concepts in necrotizing enterocolitis. Curr Opin Pediatr. 2001; 13:111115. [PubMed: 11317050]

76. Halpern MD, Holubec H, Dominguez JA, et al. Up-regulation of IL-18 and IL-12 in the ileum of neonatal rats with necrotizing enterocolitis. Pediatr Res. 2002; 51:733-739. [PubMed: 12032269]

77. Ford H, Watkins S, Reblock K, et al. The role of inflammatory cytokines and nitric oxide in the pathogenesis of necrotizing enterocolitis. J Pediatr Surg. 1997; 32:275-282. [PubMed: 9044137]

78. Edelson MB, Bagwell CE, Rozycki HJ. Circulating pro- and counterinflammatory cytokine levels and severity in necrotizing enterocolitis. Pediatrics. 1999; 103:766-771. [PubMed: 10103300]

79. Caplan MS, Simon D, Jilling T. The role of PAF, TLR, and the inflammatory response in neonatal necrotizing enterocolitis. Semin Pediatr Surg. 2005; 14:145-151. [PubMed: 16084401]

80. Kuhn R, Lohler J, Rennick D, et al. Interleukin-10-deficient mice develop chronic enterocolitis. Cell. 1993; 75:263-274. [PubMed: 8402911]

81. Halpern MD, Dominguez JA, Dvorak K, et al. Ileal cytokine dysregulation in experimental necrotizing enterocolitis is reduced by epidermal growth factor. J Pediatr Gastroenterol Nutr. 2003; 36:126-133. [PubMed: 12500008]

82. Jilling T, Lu J, Jackson M, et al. Intestinal epithelial apoptosis initiates gross bowel necrosis in an experimental rat model of neonatal necrotizing enterocolitis. Pediatr Res. 2004; 55:622-629. [PubMed: 14764921]

83. Clark JA, Lane RH, Maclennan NK, et al. Epidermal growth factor reduces intestinal apoptosis in an experimental model of necrotizing enterocolitis. Am J Physiol Gastrointest Liver Physiol. 2005; 288:G755-G762. [PubMed: 15528252]

84. Maynard AA, Dvorak K, Khailova L, et al. Epidermal growth factor reduces autophagy in intestinal epithelium and in the rat model of necrotizing enterocolitis. Am J Physiol Gastrointest Liver Physiol. 2010; 299:G614-G622. [PubMed: 20539009]

85. Shin CE, Falcone RA Jr. Stuart L, et al. Diminished epidermal growth factor levels in infants with necrotizing enterocolitis. J Pediatr Surg. 2000; 35:173-176. [PubMed: 10693661]

86. Helmrath MA, Shin CE, Fox JW, et al. Epidermal growth factor in saliva and serum of infants with necrotising enterocolitis. Lancet. 1998; 351:266-267. [PubMed: 9457103]

87. Scott SM, Rogers C, Angelus P, et al. Effect of necrotizing enterocolitis on urinary epidermal growth factor levels. Am J Dis Child. 1991; 145:804-807. [PubMed: 2058613]

88. Evans NJ, Rutter N, Gregory H. Urinary excretion of epidermal growth factor in the newborn. Early Hum Dev. 1986; 14:277-282. [PubMed: 3492360]

89. Scott SM, Guardian CM, Angelus P, et al. Developmental pattern of urinary epidermal growth factor in the premature infant and the influence of gender. J Clin Endocrinol Metab. 1991; 72:588593. [PubMed: 1997512] 
90. Tsau YK, Teng RJ, Chen CH. Correlation between urinary epidermal growth factor excretion and serum thyroid hormone in premature and term neonates. Nephron. 1998; 78:168-171. [PubMed: 9496733]

91. McGuire W, Anthony MY. Donor human milk versus formula for preventing necrotising enterocolitis in preterm infants: systematic review. Arch Dis Child Fetal Neonatal Ed. 2003; 88:F11-F14. [PubMed: 12496220]

92. Lucas A, Cole TJ. Breast milk and neonatal necrotising enterocolitis. Lancet. 1990; 336:1519_ 1523. [PubMed: 1979363]

93. Dvorak B, Halpern MD, Holubec H, et al. Maternal milk reduces severity of necrotizing enterocolitis and increases intestinal IL-10 in a neonatal rat model. Pediatr Res. 2003; 53:426-433. [PubMed: 12595590]

94. Dvorak B, Fituch CC, Williams CS, et al. Increased epidermal growth factor levels in human milk of mothers with extremely premature infants. Pediatr Res. 2003; 54:15-19. [PubMed: 12646719]

95. Matsuoka Y, Idota T. The concentration of epidermal growth factor in Japanese mother's milk. J Nutr Sci Vitaminol (Tokyo). 1995; 41:241-251. [PubMed: 7562117]

96. Yagi H, Suzuki S, Noji T, et al. Epidermal growth factor in cow's milk and milk formulas. Acta Paediatr Scand. 1986; 75:233-235. [PubMed: 3485884]

97. Dvorak B, Fituch CC, Williams CS, et al. Concentrations of epidermal growth factor and transforming growth factor-alpha in preterm milk. Adv Exp Med Biol. 2004; 554:407-409. [PubMed: 15384612]

98. Sullivan PB, Brueton MJ, Tabara ZB, et al. Epidermal growth factor in necrotising enteritis. Lancet. 1991; 338:53-54. [PubMed: 1676104]

99. Sullivan PB, Lewindon PJ, Cheng C, et al. Intestinal mucosa remodeling by recombinant human epidermal growth factor(1-48) in neonates with severe necrotizing enterocolitis. J Pediatr Surg. 2007; 42:462-469. [PubMed: 17336181]

100. vis-Fleischer KM, Besner GE. Structure and function of heparin-binding EGF-like growth factor (HB-EGF). Front Biosci. 1998; 3:d288-d299. [PubMed: 9473209]

101. Besner G, Higashiyama S, Klagsbrun M. Isolation and characterization of a macrophage-derived heparin-binding growth factor. Cell Regul. 1990; 1:811-819. [PubMed: 2088527]

102. Michalsky MP, Lara-Marquez M, Chun L, et al. Heparin-binding EGF-like growth factor is present in human amniotic fluid and breast milk. J Pediatr Surg. 2002; 37:1-6. [PubMed: 11781977]

103. Jin K, Mao XO, Sun Y, et al. Heparin-binding epidermal growth factor-like growth factor: hypoxia-inducible expression in vitro and stimulation of neurogenesis in vitro and in vivo. $\mathrm{J}$ Neurosci. 2002; 22:5365-5373. [PubMed: 12097488]

104. Cribbs RK, Harding PA, Luquette MH, et al. Endogenous production of heparin-binding EGFlike growth factor during murine partial-thickness burn wound healing. J Burn Care Rehabil. 2002; 23:116-125. [PubMed: 11882801]

105. Marikovsky M, Breuing K, Liu PY, et al. Appearance of heparin-binding EGF-like growth factor in wound fluid as a response to injury. Proc Natl Acad Sci U S A. 1993; 90:3889-3893. [PubMed: 8483908]

106. Feng J, El-Assal ON, Besner GE. Heparin-binding EGF-like growth factor (HB-EGF) and necrotizing enterocolitis. Semin Pediatr Surg. 2005; 14:167-174. [PubMed: 16084404]

107. Ellis PD, Hadfield KM, Pascall JC, et al. Heparin-binding epidermal-growth-factor-like growth factor gene expression is induced by scrape-wounding epithelial cell monolayers: involvement of mitogen-activated protein kinase cascades. Biochem J. 2001; 354:99-106. [PubMed: 11171084]

108. Xia G, Rachfal AW, Martin AE, et al. Upregulation of endogenous heparin-binding EGF-like growth factor (HB-EGF) expression after intestinal ischemia/reperfusion injury. J Invest Surg. 2003; 16:57-63. [PubMed: 12746188]

109. El-Assal ON, Besner GE. HB-EGF enhances restitution after intestinal ischemia/reperfusion via PI3K/Akt and MEK/ERK1/2 activation. Gastroenterology. 2005; 129:609-625. [PubMed: 16083716] 
110. Xia G, Martin AE, Michalsky MP, et al. Heparin-binding EGF-like growth factor preserves crypt cell proliferation and decreases bacterial translocation after intestinal ischemia/reperfusion injury. J Pediatr Surg. 2002; 37:1081-1087. [PubMed: 12077776]

111. Chen CL, Yu X, James IO, et al. Heparin-binding EGF-like growth factor protects intestinal stem cells from injury in a rat model of necrotizing enterocolitis. Lab Invest. 2012; 92:331-344. [PubMed: 22157721]

112. Luo CC, Ming YC, Chao HC, et al. Heparin-binding epidermal growth factor-like growth factor downregulates expression of activator protein-1 transcription factor after intestinal ischemiareperfusion injury. Neonatology. 2011; 99:241-246. [PubMed: 21063128]

113. Feng J, El-Assal ON, Besner GE. Heparin-binding epidermal growth factor-like growth factor decreases the incidence of necrotizing enterocolitis in neonatal rats. J Pediatr Surg. 2006; 41:144-149. [PubMed: 16410124]

114. Feng J, El-Assal ON, Besner GE. Heparin-binding epidermal growth factor-like growth factor reduces intestinal apoptosis in neonatal rats with necrotizing enterocolitis. J Pediatr Surg. 2006; 41:742-747. [PubMed: 16567187]

115. Feng J, Besner GE. Heparin-binding epidermal growth factor-like growth factor promotes enterocyte migration and proliferation in neonatal rats with necrotizing enterocolitis. J Pediatr Surg. 2007; 42:214-220. [PubMed: 17208569]

116. Yu X, Radulescu A, Zorko N, et al. Heparin-binding EGF-like growth factor increases intestinal microvascular blood flow in necrotizing enterocolitis. Gastroenterology. 2009; 137:221-230. [PubMed: 19361505]

117. Radulescu A, Zhang HY, Yu X, et al. Heparin-binding epidermal growth factor-like growth factor overexpression in transgenic mice increases resistance to necrotizing enterocolitis. J Pediatr Surg. 2010; 45:1933-1939. [PubMed: 20920709]

118. Radulescu A, Yu X, Orvets ND, et al. Deletion of the heparin-binding epidermal growth factorlike growth factor gene increases susceptibility to necrotizing enterocolitis. J Pediatr Surg. 2010; 45:729-734. [PubMed: 20385279]

119. Yang J, Watkins D, Chen CL, et al. Heparin-binding epidermal growth factor-like growth factor and mesenchymal stem cells act synergistically to prevent experimental necrotizing enterocolitis. J Am Coll Surg. 2012; 215:534-545. [PubMed: 22819639]

120. Dvorak B, Khailova L, Clark JA, et al. Comparison of epidermal growth factor and heparinbinding epidermal growth factor-like growth factor for prevention of experimental necrotizing enterocolitis. J Pediatr Gastroenterol Nutr. 2008; 47:11-18. [PubMed: 18607263]

121. Radulescu A, Zorko NA, Yu X, et al. Preclinical neonatal rat studies of heparin-binding EGF-like growth factor in protection of the intestines from necrotizing enterocolitis. Pediatr Res. 2009; 65:437-442. [PubMed: 19127210]

122. Roberge JN, Brubaker PL. Regulation of intestinal proglucagon-derived peptide secretion by glucose-dependent insulinotropic peptide in a novel enteroendocrine loop. Endocrinology. 1993; 133:233-240. [PubMed: 8319572]

123. Roberge JN, Brubaker PL. Secretion of proglucagon-derived peptides in response to intestinal luminal nutrients. Endocrinology. 1991; 128:3169-3174. [PubMed: 2036983]

124. Munroe DG, Gupta AK, Kooshesh F, et al. Prototypic G protein-coupled receptor for the intestinotrophic factor glucagon-like peptide 2. Proc Natl Acad Sci U S A. 1999; 96:1569-1573. [PubMed: 9990065]

125. Yusta B, Huang L, Munroe D, et al. Enteroendocrine localization of GLP-2 receptor expression in humans and rodents. Gastroenterology. 2000; 119:744-755. [PubMed: 10982769]

126. Thulesen J, Hartmann B, Orskov C, et al. Potential targets for glucagon-like peptide 2 (GLP-2) in the rat: distribution and binding of i.v. injected (125)I-GLP-2. Peptides. 2000; 21:1511-1517. [PubMed: 11068098]

127. Bjerknes M, Cheng H. Modulation of specific intestinal epithelial progenitors by enteric neurons. Proc Natl Acad Sci U S A. 2001; 98:12497-12502. [PubMed: 11572941]

128. Orskov C, Hartmann B, Poulsen SS, et al. GLP-2 stimulates colonic growth via KGF, released by subepithelial myofibroblasts with GLP-2 receptors. Regul Pept. 2005; 124:105-112. [PubMed: 15544847] 
129. Rowland KJ, Brubaker PL. The "cryptic" mechanism of action of glucagon-like peptide-2. Am J Physiol Gastrointest Liver Physiol. 2011; 301:G1-G8. [PubMed: 21527727]

130. Yusta B, Holland D, Waschek JA, et al. Intestinotrophic glucagon-like peptide-2 (GLP-2) activates intestinal gene expression and growth factor-dependent pathways independent of the vasoactive intestinal peptide gene in mice. Endocrinology. 2012; 153:2623-2632. [PubMed: 22535770]

131. Sigalet DL, Wallace LE, Holst JJ, et al. Enteric neural pathways mediate the anti-inflammatory actions of glucagon-like peptide 2. Am J Physiol Gastrointest Liver Physiol. 2007; 293:G211G221. [PubMed: 17395898]

132. Dube PE, Rowland KJ, Brubaker PL. Glucagon-like peptide-2 activates beta-catenin signaling in the mouse intestinal crypt: role of insulin-like growth factor-I. Endocrinology. 2008; 149:291301. [PubMed: 17884945]

133. Rowland KJ, Trivedi S, Lee D, et al. Loss of glucagon-like peptide-2-induced proliferation following intestinal epithelial insulin-like growth factor-1-receptor deletion. Gastroenterology. 2011; 141:2166-2175. [PubMed: 21925122]

134. Dube PE, Forse CL, Bahrami J, et al. The essential role of insulin-like growth factor-1 in the intestinal tropic effects of glucagon-like peptide-2 in mice. Gastroenterology. 2006; 131:589_ 605. [PubMed: 16890611]

135. Leen JL, Izzo A, Upadhyay C, et al. Mechanism of action of glucagon-like peptide-2 to increase IGF-I mRNA in intestinal subepithelial fibroblasts. Endocrinology. 2011; 152:436-446. [PubMed: 21159855]

136. Liu X, Murali SG, Holst JJ, et al. Enteral nutrients potentiate the intestinotrophic action of glucagon-like peptide-2 in association with increased insulin-like growth factor-I responses in rats. Am J Physiol Regul Integr Comp Physiol. 2008; 295:R1794-R1802. [PubMed: 18832087]

137. Lee YC, Brubaker PL, Drucker DJ. Developmental and tissue-specific regulation of proglucagon gene expression. Endocrinology. 1990; 127:2217-2222. [PubMed: 2226310]

138. Lovshin J, Yusta B, Iliopoulos I, et al. Ontogeny of the glucagon-like peptide-2 receptor axis in the developing rat intestine. Endocrinology. 2000; 141:4194-4201. [PubMed: 11089553]

139. Brubaker PL, Izzo A, Hill M, et al. Intestinal function in mice with small bowel growth induced by glucagon-like peptide-2. Am J Physiol. 1997; 272:E1050-E1058. [PubMed: 9227451]

140. Petersen YM, Elnif J, Schmidt M, et al. Glucagon-like peptide 2 enhances maltaseglucoamylase and sucrase-isomaltase gene expression and activity in parenterally fed premature neonatal piglets. Pediatr Res. 2002; 52:498-503. [PubMed: 12357042]

141. Amin H, Holst JJ, Hartmann B, et al. Functional ontogeny of the proglucagon-derived peptide axis in the premature human neonate. Pediatrics. 2008; 121:e180-e186. [PubMed: 18166537]

142. Meier JJ, Nauck MA, Pott A, et al. Glucagon-like peptide 2 stimulates glucagon secretion, enhances lipid absorption, and inhibits gastric acid secretion in humans. Gastroenterology. 2006; 130:44-54. [PubMed: 16401467]

143. Cameron HL, Yang PC, Perdue MH. Glucagon-like peptide-2-enhanced barrier function reduces pathophysiology in a model of food allergy. Am J Physiol Gastrointest Liver Physiol. 2003; 284:G905-G912. [PubMed: 12736145]

144. Benjamin MA, McKay DM, Yang PC, et al. Glucagon-like peptide-2 enhances intestinal epithelial barrier function of both transcellular and paracellular pathways in the mouse. Gut. 2000; 47:112-119. [PubMed: 10861272]

145. Kouris GJ, Liu Q, Rossi H, et al. The effect of glucagon-like peptide 2 on intestinal permeability and bacterial translocation in acute necrotizing pancreatitis. Am J Surg. 2001; 181:571-575. [PubMed: 11513789]

146. Drucker DJ. Epithelial cell growth and differentiation. I. Intestinal growth factors. Am J Physiol. 1997; 273:G3-G6. [PubMed: 9252503]

147. Tsai CH, Hill M, Asa SL, et al. Intestinal growth-promoting properties of glucagon-like peptide-2 in mice. Am J Physiol. 1997; 273:E77-E84. [PubMed: 9252482]

148. Burrin DG, Stoll B, Guan X, et al. Glucagon-like peptide 2 dose-dependently activates intestinal cell survival and proliferation in neonatal piglets. Endocrinology. 2005; 146:22-32. [PubMed: 15486229] 
149. Cheeseman CI. Upregulation of SGLT-1 transport activity in rat jejunum induced by GLP-2 infusion in vivo. Am J Physiol. 1997; 273:R1965-R1971. [PubMed: 9435650]

150. Cheeseman CI, Tsang R. The effect of GIP and glucagon-like peptides on intestinal basolateral membrane hexose transport. Am J Physiol. 1996; 271:G477-G482. [PubMed: 8843773]

151. Ramsanahie AP, Berger UV, Zinner MJ, et al. Effect of glucagon-like peptide-2 (GLP-2) on diurnal SGLT1 expression. Dig Dis Sci. 2004; 49:1731-1737. [PubMed: 15628694]

152. Bremholm L, Hornum M, Henriksen BM, et al. Glucagon-like peptide-2 increases mesenteric blood flow in humans. Scand J Gastroenterol. 2009; 44:314-319. [PubMed: 19005872]

153. Guan X, Stoll B, Lu X, et al. GLP-2-mediated up-regulation of intestinal blood flow and glucose uptake is nitric oxide-dependent in TPN-fed piglets 1. Gastroenterology. 2003; 125:136-147. [PubMed: 12851879]

154. Buchman AL, Katz S, Fang JC, et al. Teduglutide, a novel mucosally active analog of glucagonlike peptide-2 (GLP-2) for the treatment of moderate to severe Crohn's disease. Inflamm Bowel Dis. 2010; 16:962-973. [PubMed: 19821509]

155. Drucker DJ, Yusta B, Boushey RP, et al. Human [Gly2]GLP-2 reduces the severity of colonic injury in a murine model of experimental colitis. Am J Physiol. 1999; 276:G79-G91. [PubMed: 9886982]

156. Boushey RP, Yusta B, Drucker DJ. Glucagon-like peptide 2 decreases mortality and reduces the severity of indomethacin-induced murine enteritis. Am J Physiol. 1999; 277:E937-E947. [PubMed: 10567023]

157. Martin GR, Wallace LE, Hartmann B, et al. Nutrient-stimulated GLP-2 release and crypt cell proliferation in experimental short bowel syndrome. Am J Physiol Gastrointest Liver Physiol. 2005; 288:G431-G438. [PubMed: 15388486]

158. Scott RB, Kirk D, MacNaughton WK, et al. GLP-2 augments the adaptive response to massive intestinal resection in rat. Am J Physiol. 1998; 275:G911-G921. [PubMed: 9815019]

159. Martin GR, Wallace LE, Sigalet DL. Glucagon-like peptide-2 induces intestinal adaptation in parenterally fed rats with short bowel syndrome. Am J Physiol Gastrointest Liver Physiol. 2004; 286:G964-G972. [PubMed: 14962847]

160. Sigalet DL, Martin G, Meddings J, et al. GLP-2 levels in infants with intestinal dysfunction. Pediatr Res. 2004; 56:371-376. [PubMed: 15201402]

161. Sigalet D, Boctor D, Brindle M, et al. Elements of successful intestinal rehabilitation. J Pediatr Surg. 2011; 46:150-156. [PubMed: 21238657]

162. Jeppesen PB, Sanguinetti EL, Buchman A, et al. Teduglutide (ALX-0600), a dipeptidyl peptidase IV resistant glucagon-like peptide 2 analogue, improves intestinal function in short bowel syndrome patients. Gut. 2005; 54:1224-1231. [PubMed: 16099790]

163. Chance WT, Sheriff S, McCarter F, et al. Glucagon-like peptide-2 stimulates gut mucosal growth and immune response in burned rats. J Burn Care Rehabil. 2001; 22:136-143. [PubMed: 11302602]

164. Zhang W, Zhu W, Zhang J, et al. Protective effects of glucagon-like peptide 2 on intestinal ischemia-reperfusion rats. Microsurgery. 2008; 28:285-290. [PubMed: 18383347]

165. Rajeevprasad R, Alavi K, Schwartz MZ. Glucagonlike peptide-2 analogue enhances intestinal mucosal mass and absorptive function after ischemia-reperfusion injury. J Pediatr Surg. 2000; 35:1537-1539. [PubMed: 11083417]

166. Cameron HL, Perdue MH. Stress impairs murine intestinal barrier function: improvement by glucagon-like peptide-2. J Pharmacol Exp Ther. 2005; 314:214-220. [PubMed: 15798004]

167. Rosenfeld RG, Hwa V. The growth hormone cascade and its role in mammalian growth. Horm Res. 2009; 71(Suppl 2):36-40. [PubMed: 19407495]

168. Lichanska AM, Waters MJ. How growth hormone controls growth, obesity and sexual dimorphism. Trends Genet. 2008; 24:41-47. [PubMed: 18063438]

169. ehaye-Zervas MC, Mertani H, Martini JF, et al. Expression of the growth hormone receptor gene in human digestive tissue. J Clin Endocrinol Metab. 1994; 78:1473-1480. [PubMed: 8200952]

170. Wheeler EE, Challacombe DN. The trophic action of growth hormone, insulin-like growth factorI, and insulin on human duodenal mucosa cultured in vitro. Gut. 1997; 40:57-60. [PubMed: 9155576] 
171. Woelfle J, Chia DJ, Rotwein P. Mechanisms of growth hormone (GH) action. Identification of conserved Stat5 binding sites that mediate GH-induced insulin-like growth factor-I gene activation. J Biol Chem. 2003; 278:51261-51266. [PubMed: 14532269]

172. Ersoy B, Ozbilgin K, Kasirga E, et al. Effect of growth hormone on small intestinal homeostasis relation to cellular mediators IGF-I and IGFBP-3. World J Gastroenterol. 2009; 15:5418-5424. [PubMed: 19916171]

173. Ulshen MH, Dowling RH, Fuller CR, et al. Enhanced growth of small bowel in transgenic mice overexpressing bovine growth hormone. Gastroenterology. 1993; 104:973-980. [PubMed: 7681797]

174. Waitzberg DL, Cukier C, Mucerino DR, et al. Small bowel adaptation with growth hormone and glutamine after massive resection of rat's small bowel. Nutr Hosp. 1999; 14:81-90. [PubMed: 10364785]

175. Fadrique B, Lopez JM, Bermudez R, et al. Growth hormone plus high protein diet promotes adaptation after massive bowel resection in aged rats. Exp Gerontol. 2001; 36:1727-1737. [PubMed: 11672992]

176. Letton RW, Chwals WJ, Jamie A, et al. Neonatal lipid utilization increases with injury severity: recombinant human growth hormone versus placebo. J Pediatr Surg. 1996; 31:1068-1072. [PubMed: 8863236]

177. Williams KL, Fuller CR, Dieleman LA, et al. Enhanced survival and mucosal repair after dextran sodium sulfate-induced colitis in transgenic mice that overexpress growth hormone. Gastroenterology. 2001; 120:925-937. [PubMed: 11231946]

178. Kara E, Sungurtekin H, Sungurtekin U, et al. The effect of recombinant human growth hormone $(\mathrm{rhGH})$ on trinitrobenzene sulfonic acid-induced colitis in rats: an experimental study. Inflamm Bowel Dis. 2004; 10:112-115. [PubMed: 15168810]

179. Denson LA, Kim MO, Bezold R, et al. A randomized controlled trial of growth hormone in active pediatric Crohn disease. J Pediatr Gastroenterol Nutr. 2010; 51:130-139. [PubMed: 20453679]

180. Zhou X, Li YX, Li N, et al. Glutamine enhances the gut-trophic effect of growth hormone in rat after massive small bowel resection. J Surg Res. 2001; 99:47-52. [PubMed: 11421603]

181. Gu Y, Wu ZH, Xie JX, et al. Effects of growth hormone (rhGH) and glutamine supplemented parenteral nutrition on intestinal adaptation in short bowel rats. Clin Nutr. 2001; 20:159-166. [PubMed: 11327744]

182. Seguy D, Vahedi K, Kapel N, et al. Low-dose growth hormone in adult home parenteral nutritiondependent short bowel syndrome patients: a positive study. Gastroenterology. 2003; 124:293302. [PubMed: 12557135]

183. Byrne TA, Morrissey TB, Nattakom TV, et al. Growth hormone, glutamine, and a modified diet enhance nutrient absorption in patients with severe short bowel syndrome. JPEN J Parenter Enteral Nutr. 1995; 19:296-302. [PubMed: 8523629]

184. Scolapio JS, Camilleri M, Fleming CR, et al. Effect of growth hormone, glutamine, and diet on adaptation in short-bowel syndrome: a randomized, controlled study. Gastroenterology. 1997; 113:1074-1081. [PubMed: 9322500]

185. Peretti N, Loras-Duclaux I, Kassai B, et al. Growth hormone to improve short bowel syndrome intestinal autonomy: a pediatric randomized open-label clinical trial. JPEN J Parenter Enteral Nutr. 2011; 35:723-731. [PubMed: 21975668]

186. Hormi K, Lehy T. Developmental expression of transforming growth factor-alpha and epidermal growth factor receptor proteins in the human pancreas and digestive tract. Cell Tissue Res. 1994; 278:439-450. [PubMed: 7850855]

187. Menard D, Pothier P. Radioautographic localization of epidermal growth factor receptors in human fetal gut. Gastroenterology. 1991; 101:640-649. [PubMed: 1860628]

188. Han VK, Lund PK, Lee DC, et al. Expression of somatomedin/insulin-like growth factor messenger ribonucleic acids in the human fetus: identification, characterization, and tissue distribution. J Clin Endocrinol Metab. 1988; 66:422-429. [PubMed: 2448331]

189. Foulstone E, Prince S, Zaccheo O, et al. Insulin-like growth factor ligands, receptors, and binding proteins in cancer. J Pathol. 2005; 205:145-153. [PubMed: 15641016] 
190. Bortvedt SF, Lund PK. Insulin-like growth factor 1: common mediator of multiple enterotrophic hormones and growth factors. Curr Opin Gastroenterol. 2012; 28:89-98. [PubMed: 22241077]

191. Conteas CN, McMorrow B, Luk GD. Modulation of epidermal growth factor-induced cell proliferation and receptor binding by insulin in cultured intestinal epithelial cells. Biochem Biophys Res Commun. 1989; 161:414-419. [PubMed: 2660787]

192. Kurokowa M, Lynch K, Podolsky DK. Effects of growth factors on an intestinal epithelial cell line: transforming growth factor beta inhibits proliferation and stimulates differentiation. Biochem Biophys Res Commun. 1987; 142:775-782. [PubMed: 3548718]

193. Duncan MD, Korman LY, Bass BL. Epidermal growth factor primes intestinal epithelial cells for proliferative effect of insulin-like growth factor I. Dig Dis Sci. 1994; 39:2197-2201. [PubMed: 7924742]

194. Ohneda K, Ulshen MH, Fuller CR, et al. Enhanced growth of small bowel in transgenic mice expressing human insulin-like growth factor I. Gastroenterology. 1997; 112:444-454. [PubMed: 9024298]

195. Theiss AL, Fruchtman S, Lund PK. Growth factors in inflammatory bowel disease: the actions and interactions of growth hormone and insulin-like growth factor-I. Inflamm Bowel Dis. 2004; 10:871-880. [PubMed: 15626905]

196. Lund PK. Molecular basis of intestinal adaptation: the role of the insulin-like growth factor system. Ann N Y Acad Sci. 1998; 859:18-36. [PubMed: 9928367]

197. Alexander AN, Carey HV. Oral IGF-I enhances nutrient and electrolyte absorption in neonatal piglet intestine. Am J Physiol. 1999; 277:G619-G625. [PubMed: 10484387]

198. Burrin DG, Wester TJ, Davis TA, et al. Orally administered IGF-I increases intestinal mucosal growth in formula-fed neonatal pigs. Am J Physiol. 1996; 270:R1085-R1091. [PubMed: 8928910]

199. Aikin R, Rosenberg L, Maysinger D. Phosphatidylinositol 3-kinase signaling to Akt mediates survival in isolated canine islets of Langerhans. Biochem Biophys Res Commun. 2000; 277:455461. [PubMed: 11032744]

200. Shepherd PR. Mechanisms regulating phosphoinositide 3-kinase signalling in insulin-sensitive tissues. Acta Physiol Scand. 2005; 183:3-12. [PubMed: 15654916]

201. Allen TR, Krueger KD, Hunter WJ III, et al. Evidence that insulin-like growth factor-1 requires protein kinase C-epsilon, PI3-kinase and mitogen-activated protein kinase pathways to protect human vascular smooth muscle cells from apoptosis. Immunol Cell Biol. 2005; 83:651-667. [PubMed: 16266318]

202. Hunninghake GW, Doerschug KC, Nymon AB, et al. Insulin-like growth factor-1 levels contribute to the development of bacterial translocation in sepsis. Am J Respir Crit Care Med. 2010; 182:517-525. [PubMed: 20413631]

203. Zhou Y, Wang Q, Evers BM, et al. Signal transduction pathways involved in oxidative stressinduced intestinal epithelial cell apoptosis. Pediatr Res. 2005; 58:1192-1197. [PubMed: 16306192]

204. Baregamian N, Song J, Jeschke MG, et al. IGF-1 protects intestinal epithelial cells from oxidative stress-induced apoptosis. J Surg Res. 2006; 136:31-37. [PubMed: 16999977]

205. Baregamian N, Rychahou PG, Hawkins HK, et al. Phosphatidylinositol 3-kinase pathway regulates hypoxia-inducible factor-1 to protect from intestinal injury during necrotizing enterocolitis. Surgery. 2007; 142:295-302. [PubMed: 17689699]

206. Hellstrom A, Engstrom E, Hard AL, et al. Postnatal serum insulin-like growth factor I deficiency is associated with retinopathy of prematurity and other complications of premature birth. Pediatrics. 2003; 112:1016-1020. [PubMed: 14595040]

207. Baregamian N, Song J, Chung DH. Effects of oxidative stress on intestinal type I insulin-like growth factor receptor expression. Eur J Pediatr Surg. 2012; 22:97-104. [PubMed: 22434232]

208. Ozen S, Akisu M, Baka M, et al. Insulin-like growth factor attenuates apoptosis and mucosal damage in hypoxia/reoxygenation-induced intestinal injury. Biol Neonate. 2005; 87:91-96. [PubMed: 15528875] 
209. Calhoun DA, Lunoe M, Du Y, et al. Concentrations of granulocyte colony-stimulating factor in human milk after in vitro simulations of digestion. Pediatr Res. 1999; 46:767-771. [PubMed: 10590037]

210. Calhoun DA, Lunoe M, Du Y, et al. Granulocyte colony-stimulating factor is present in human milk and its receptor is present in human fetal intestine. Pediatrics. 2000; 105:e7. [PubMed: 10617744]

211. Calhoun DA, Christensen RD. Human developmental biology of granulocyte colony-stimulating factor. Clin Perinatol. 2000; 27:559-76. [PubMed: 10986629]

212. Weimann E, Rutkowski S, Reisbach G. G-CSF, GM-CSF and IL-6 levels in cord blood: diminished increase of G-CSF and IL-6 in preterms with perinatal infection compared to term neonates. J Perinat Med. 1998; 26:211-218. [PubMed: 9773382]

213. Calhoun DA, Donnelly WH Jr. Du Y, et al. Distribution of granulocyte colony-stimulating factor (G-CSF) and G-CSF-receptor mRNA and protein in the human fetus. Pediatr Res. 1999; 46:333338. [PubMed: 10473051]

214. MohanKumar K, Kaza N, Jagadeeswaran R, et al. Gut mucosal injury in neonates is marked by macrophage infiltration in contrast to pleomorphic infiltrates in adult: evidence from an animal model. Am J Physiol Gastrointest Liver Physiol. 2012; 303:G93-102. [PubMed: 22538401]

215. Emami CN, Mittal R, Wang L, et al. Role of neutrophils and macrophages in the pathogenesis of necrotizing enterocolitis caused by Cronobacter sakazakii. J Surg Res. 2012; 172:18-28. [PubMed: 21601887]

216. Zhang C, Xu YG, Duan XN, et al. Role of granulocyte colony-stimulating factor in paclitaxelinduced intestinal barrier breakdown and bacterial translocation in rats. Chin Med J (Engl). 2011; 124:1870-1875. [PubMed: 21866617]

217. Canpolat FE, Yurdakok M, Ozsoy S, et al. Protective effects of recombinant human granulocyte colony stimulating factor in a rat model of necrotizing enterocolitis. Pediatr Surg Int. 2006; 22:719-723. [PubMed: 16871399]

218. Canpolat FE, Yurdakok M, Korkmaz A, et al. Enteral granulocyte colony-stimulating factor for the treatment of mild (stage I) necrotizing enterocolitis: a placebo-controlled pilot study. J Pediatr Surg. 2006; 41:1134-1138. [PubMed: 16769348]

219. Krantz SB. Erythropoietin. Blood. 1991; 77:419-434.

220. Arcasoy MO. The non-haematopoietic biological effects of erythropoietin. Br J Haematol. 2008; 141:14-31. [PubMed: 18324962]

221. Carmichael RD, LoBue J, Gordon AS. Neonatal erythropoiesis. II. Bone marrow and splenic erythropoietic activity: data suggest erythropoietin transfer via maternal milk. Endocr Regul. 1992; 26:143-149. [PubMed: 1308157]

222. Kling PJ, Sullivan TM, Roberts RA, et al. Human milk as a potential enteral source of erythropoietin. Pediatr Res. 1998; 43:216-221. [PubMed: 9475287]

223. Clapp JF III, Little KD, ppleby-Wineberg SK, et al. The effect of regular maternal exercise on erythropoietin in cord blood and amniotic fluid. Am J Obstet Gynecol. 1995; 172:1445-1451. [PubMed: 7755052]

224. Richey SD, Ramin SM, Bawdon RE, et al. Markers of acute and chronic asphyxia in infants with meconium-stained amniotic fluid. Am J Obstet Gynecol. 1995; 172:1212-1215. [PubMed: 7726258]

225. Juul SE, Zhao Y, Dame JB, et al. Origin and fate of erythropoietin in human milk. Pediatr Res. 2000; 48:660-667. [PubMed: 11044488]

226. Carmichael RD, LoBue J, Gordon AS. Neonatal erythropoiesis. I. Peripheral blood erythropoietic parameters: data suggest erythropoietin transfer via maternal milk. Endocr Regul. 1992; 26:8388. [PubMed: 1472693]

227. Juul SE, Joyce AE, Zhao Y, et al. Why is erythropoietin present in human milk? Studies of erythropoietin receptors on enterocytes of human and rat neonates. Pediatr Res. 1999; 46:263268. [PubMed: 10473039]

228. Juul SE, Yachnis AT, Christensen RD. Tissue distribution of erythropoietin and erythropoietin receptor in the developing human fetus. Early Hum Dev. 1998; 52:235-249. [PubMed: 9808074] 
229. Claud EC, Savidge T, Walker WA. Modulation of human intestinal epithelial cell IL-8 secretion by human milk factors. Pediatr Res. 2003; 53:419-425. [PubMed: 12595589]

230. Kumral A, Baskin H, Duman N, et al. Erythropoietin protects against necrotizing enterocolitis of newborn rats by the inhibiting nitric oxide formation. Biol Neonate. 2003; 84:325-329. [PubMed: 14593244]

231. Shiou SR, Yu Y, Chen S, et al. Erythropoietin protects intestinal epithelial barrier function and lowers the incidence of experimental neonatal necrotizing enterocolitis. J Biol Chem. 2011; 286:12123-12132. [PubMed: 21262973]

232. Ledbetter DJ, Juul SE. Erythropoietin and the incidence of necrotizing enterocolitis in infants with very low birth weight. J Pediatr Surg. 2000; 35:178-181. [PubMed: 10693662]

233. Thim L. Trefoil peptides: a new family of gastrointestinal molecules. Digestion. 1994; 55:353360. [PubMed: 7705547]

234. Wright NA, Poulsom R, Stamp G, et al. Trefoil peptide gene expression in gastrointestinal epithelial cells in inflammatory bowel disease. Scand J Gastroenterol Suppl. 1992; 193:76-82. [PubMed: 1290063]

235. Wright NA, Poulsom R, Stamp GW, et al. Epidermal growth factor (EGF/URO) induces expression of regulatory peptides in damaged human gastrointestinal tissues. J Pathol. 1990; 162:279-284. [PubMed: 2290113]

236. Rio MC, Chenard MP, Wolf C, et al. Induction of pS2 and hSP genes as markers of mucosal ulceration of the digestive tract. Gastroenterology. 1991; 100:375-379. [PubMed: 1985035]

237. Taupin DR, Kinoshita K, Podolsky DK. Intestinal trefoil factor confers colonic epithelial resistance to apoptosis. Proc Natl Acad Sci U S A. 2000; 97:799-804. [PubMed: 10639160]

238. Sands BE, Podolsky DK. The trefoil peptide family. Annu Rev Physiol. 1996; 58:253-273. [PubMed: 8815795]

239. Durer U, Hartig R, Bang S, et al. TFF3 and EGF induce different migration patterns of intestinal epithelial cells in vitro and trigger increased internalization of E-cadherin. Cell Physiol Biochem. 2007; 20:329-346. [PubMed: 17762162]

240. Tran CP, Cook GA, Yeomans ND, et al. Trefoil peptide TFF2 (spasmolytic polypeptide) potently accelerates healing and reduces inflammation in a rat model of colitis. Gut. 1999; 44:636-642. [PubMed: 10205199]

241. Vandenbroucke K, Hans W, Van HJ, et al. Active delivery of trefoil factors by genetically modified Lactococcus lactis prevents and heals acute colitis in mice. Gastroenterology. 2004; 127:502-513. [PubMed: 15300583]

242. Beck PL, Wong JF, Li Y, et al. Chemotherapy- and radiotherapy-induced intestinal damage is regulated by intestinal trefoil factor. Gastroenterology. 2004; 126:796-808. [PubMed: 14988834]

243. Mashimo H, Wu DC, Podolsky DK, et al. Impaired defense of intestinal mucosa in mice lacking intestinal trefoil factor. Science. 1996; 274:262-265. [PubMed: 8824194]

244. Lin J, Holzman IR, Jiang P, et al. Expression of intestinal trefoil factor in developing rat intestine. Biol Neonate. 1999; 76:92-97. [PubMed: 10393993]

245. Shi L, Zhang BH, Yu HG, et al. Intestinal trefoil factor in treatment of neonatal necrotizing enterocolitis in the rat model. J Perinat Med. 2007; 35:443-446. [PubMed: 17624936]

246. Finch PW, Rubin JS, Miki T, et al. Human KGF is FGF-related with properties of a paracrine effector of epithelial cell growth. Science. 1989; 245:752-755. [PubMed: 2475908]

247. Housley RM, Morris CF, Boyle W, et al. Keratinocyte growth factor induces proliferation of hepatocytes and epithelial cells throughout the rat gastrointestinal tract. J Clin Invest. 1994; 94:1764-1777. [PubMed: 7962522]

248. Chailler P, Basque JR, Corriveau L, et al. Functional characterization of the keratinocyte growth factor system in human fetal gastrointestinal tract. Pediatr Res. 2000; 48:504-510. [PubMed: 11004242]

249. Brauchle M, Madlener M, Wagner AD, et al. Keratinocyte growth factor is highly overexpressed in inflammatory bowel disease. Am J Pathol. 1996; 149:521-529. [PubMed: 8701991]

250. Zeeh JM, Procaccino F, Hoffmann P, et al. Keratinocyte growth factor ameliorates mucosal injury in an experimental model of colitis in rats. Gastroenterology. 1996; 110:1077-1083. [PubMed: 8612996] 
251. Liu CJ, Jin JD, Lv TD, et al. Keratinocyte growth factor gene therapy ameliorates ulcerative colitis in rats. World J Gastroenterol. 2011; 17:2632-2640. [PubMed: 21677832]

252. Wildhaber BE, Yang H, Teitelbaum DH. Keratinocyte growth factor decreases total parenteral nutrition-induced apoptosis in mouse intestinal epithelium via Bcl-2. J Pediatr Surg. 2003; 38:92-96. [PubMed: 12592627]

253. Khan WB, Shui C, Ning S, et al. Enhancement of murine intestinal stem cell survival after irradiation by keratinocyte growth factor. Radiat Res. 1997; 148:248-253. [PubMed: 9291356]

254. Farrell CL, Bready JV, Rex KL, et al. Keratinocyte growth factor protects mice from chemotherapy and radiation-induced gastrointestinal injury and mortality. Cancer Res. 1998; 58:933-939. [PubMed: 9500453]

255. Chen Y, Chou K, Fuchs E, et al. Protection of the intestinal mucosa by intraepithelial gamma delta T cells. Proc Natl Acad Sci U S A. 2002; 99:14338-14343. [PubMed: 12376619]

256. Sandborn WJ, Sands BE, Wolf DC, et al. Repifermin (keratinocyte growth factor-2) for the treatment of active ulcerative colitis: a randomized, double-blind, placebo-controlled, doseescalation trial. Aliment Pharmacol Ther. 2003; 17:1355-1364. [PubMed: 12786629]

257. Boros P, Miller CM. Hepatocyte growth factor: a multifunctional cytokine. Lancet. 1995; 345:293-295. [PubMed: 7837864]

258. Zarnegar R, Michalopoulos GK. The many faces of hepatocyte growth factor: from hepatopoiesis to hematopoiesis. J Cell Biol. 1995; 129:1177-1180. [PubMed: 7775566]

259. Kermorgant S, Walker F, Hormi K, et al. Developmental expression and functionality of hepatocyte growth factor and c-Met in human fetal digestive tissues. Gastroenterology. 1997; 112:1635-1647. [PubMed: 9136843]

260. Wang Y, Harvey C, Rousset M, et al. Expression of human intestinal mRNA transcripts during development: analysis by a semiquantitative RNA polymerase chain reaction method. Pediatr Res. 1994; 36:514-521. [PubMed: 7816528]

261. Miyazawa K, Shimomura T, Kitamura A, et al. Molecular cloning and sequence analysis of the cDNA for a human serine protease reponsible for activation of hepatocyte growth factor. Structural similarity of the protease precursor to blood coagulation factor XII. J Biol Chem. 1993; 268:10024-10028. [PubMed: 7683665]

262. Itoh H, Hamasuna R, Kataoka H, et al. Mouse hepatocyte growth factor activator gene: its expression not only in the liver but also in the gastrointestinal tract. Biochim Biophys Acta. 2000; 1491:295-302. [PubMed: 10760594]

263. Miyazawa K, Shimomura T, Naka D, et al. Proteolytic activation of hepatocyte growth factor in response to tissue injury. J Biol Chem. 1994; 269:8966-8970. [PubMed: 8132634]

264. Itoh H, Kataoka H, Tomita M, et al. Upregulation of HGF activator inhibitor type 1 but not type 2 along with regeneration of intestinal mucosa. Am J Physiol Gastrointest Liver Physiol. 2000; 278:G635-G643. [PubMed: 10762618]

265. Nishimura S, Takahashi M, Ota S, et al. Hepatocyte growth factor accelerates restitution of intestinal epithelial cells. J Gastroenterol. 1998; 33:172-178. [PubMed: 9605945]

266. Ido A, Numata M, Kodama M, et al. Mucosal repair and growth factors: recombinant human hepatocyte growth factor as an innovative therapy for inflammatory bowel disease. $\mathrm{J}$ Gastroenterol. 2005; 40:925-931. [PubMed: 16261428]

267. Mammen JM, Matthews JB. Mucosal repair in the gastrointestinal tract. Crit Care Med. 2003; 31:S532-S537. [PubMed: 12907883]

268. Grenier A, Chollet-Martin S, Crestani B, et al. Presence of a mobilizable intracellular pool of hepatocyte growth factor in human polymorphonuclear neutrophils. Blood. 2002; 99:2997-3004. [PubMed: 11929792]

269. Nakamura T, Nawa K, Ichihara A, et al. Purification and subunit structure of hepatocyte growth factor from rat platelets. FEBS Lett. 1987; 224:311-316. [PubMed: 3319692]

270. Schmidt C, Bladt F, Goedecke S, et al. Scatter factor/hepatocyte growth factor is essential for liver development. Nature. 1995; 373:699-702. [PubMed: 7854452]

271. Uehara Y, Minowa O, Mori C, et al. Placental defect and embryonic lethality in mice lacking hepatocyte growth factor/scatter factor. Nature. 1995; 373:702-705. [PubMed: 7854453] 
272. Itoh H, Naganuma S, Takeda N, et al. Regeneration of injured intestinal mucosa is impaired in hepatocyte growth factor activator-deficient mice. Gastroenterology. 2004; 127:1423-1435. [PubMed: 15521012]

273. Kato Y, Yu D, Schwartz MZ. Enhancement of intestinal adaptation by hepatocyte growth factor. J Pediatr Surg. 1998; 33:235-239. [PubMed: 9498393]

274. Schwartz MZ, Kato Y, Yu D, et al. Growth-factor enhancement of compromised gut function following massive small-bowel resection. Pediatr Surg Int. 2000; 16:174-175. [PubMed: 10786975]

275. Jeschke MG, Bolder U, Finnerty CC, et al. The effect of hepatocyte growth factor on gut mucosal apoptosis and proliferation, and cellular mediators after severe trauma. Surgery. 2005; 138:482489. [PubMed: 16213902]

276. Tahara Y, Ido A, Yamamoto S, et al. Hepatocyte growth factor facilitates colonic mucosal repair in experimental ulcerative colitis in rats. J Pharmacol Exp Ther. 2003; 307:146-151. [PubMed: 12954797]

277. Numata M, Ido A, Moriuchi A, et al. Hepatocyte growth factor facilitates the repair of large colonic ulcers in 2,4,6-trinitrobenzene sulfonic acid-induced colitis in rats. Inflamm Bowel Dis. 2005; 11:551-558. [PubMed: 15905702]

278. Kuenzler KA, Pearson PY, Schwartz MZ. Hepatocyte growth factor pretreatment reduces apoptosis and mucosal damage after intestinal ischemia-reperfusion. J Pediatr Surg. 2002; 37:1093-1097. [PubMed: 12077779]

279. Weil BR, Markel TA, Herrmann JL, et al. Mesenchymal stem cells enhance the viability and proliferation of human fetal intestinal epithelial cells following hypoxic injury via paracrine mechanisms. Surgery. 2009; 146:190-197. [PubMed: 19628073]

280. Sakata H, Takayama H, Sharp R, et al. Hepatocyte growth factor/scatter factor overexpression induces growth, abnormal development, and tumor formation in transgenic mouse livers. Cell Growth Differ. 1996; 7:1513-1523. [PubMed: 8930401]

281. Takayama H, LaRochelle WJ, Sharp R, et al. Diverse tumorigenesis associated with aberrant development in mice overexpressing hepatocyte growth factor/scatter factor. Proc Natl Acad Sci U S A. 1997; 94:701-706. [PubMed: 9012848]

282. Gallego MI, Bierie B, Hennighausen L. Targeted expression of HGF/SF in mouse mammary epithelium leads to metastatic adenosquamous carcinomas through the activation of multiple signal transduction pathways. Oncogene. 2003; 22:8498-8508. [PubMed: 14627990]

283. Bell A, Chen Q, DeFrances MC, et al. The five amino acid-deleted isoform of hepatocyte growth factor promotes carcinogenesis in transgenic mice. Oncogene. 1999; 18:887-895. [PubMed: 10023664]

284. Chinery R, Playford RJ. Combined intestinal trefoil factor and epidermal growth factor is prophylactic against indomethacin-induced gastric damage in the rat. Clin Sci (Lond). 1995; 88:401-403. [PubMed: 7789040]

285. Cibrian D, Ajamieh H, Berlanga J, et al. Use of growth-hormone-releasing peptide-6 (GHRP-6) for the prevention of multiple organ failure. Clin Sci (Lond). 2006; 110:563-573. [PubMed: 16417467]

286. Jacobs DO, Evans DA, Mealy K, et al. Combined effects of glutamine and epidermal growth factor on the rat intestine. Surgery. 1988; 104:358-364. [PubMed: 3135628]

287. Ko TC, Beauchamp RD, Townsend CM Jr. et al. Glutamine is essential for epidermal growth factor-stimulated intestinal cell proliferation. Surgery. 1993; 114:147-153. [PubMed: 7688149]

288. Zhang W, Bain A, Rombeau JL. Insulin-like growth factor-I (IGF-I) and glutamine improve structure and function in the small bowel allograft. J Surg Res. 1995; 59:6-12. [PubMed: 7630138] 


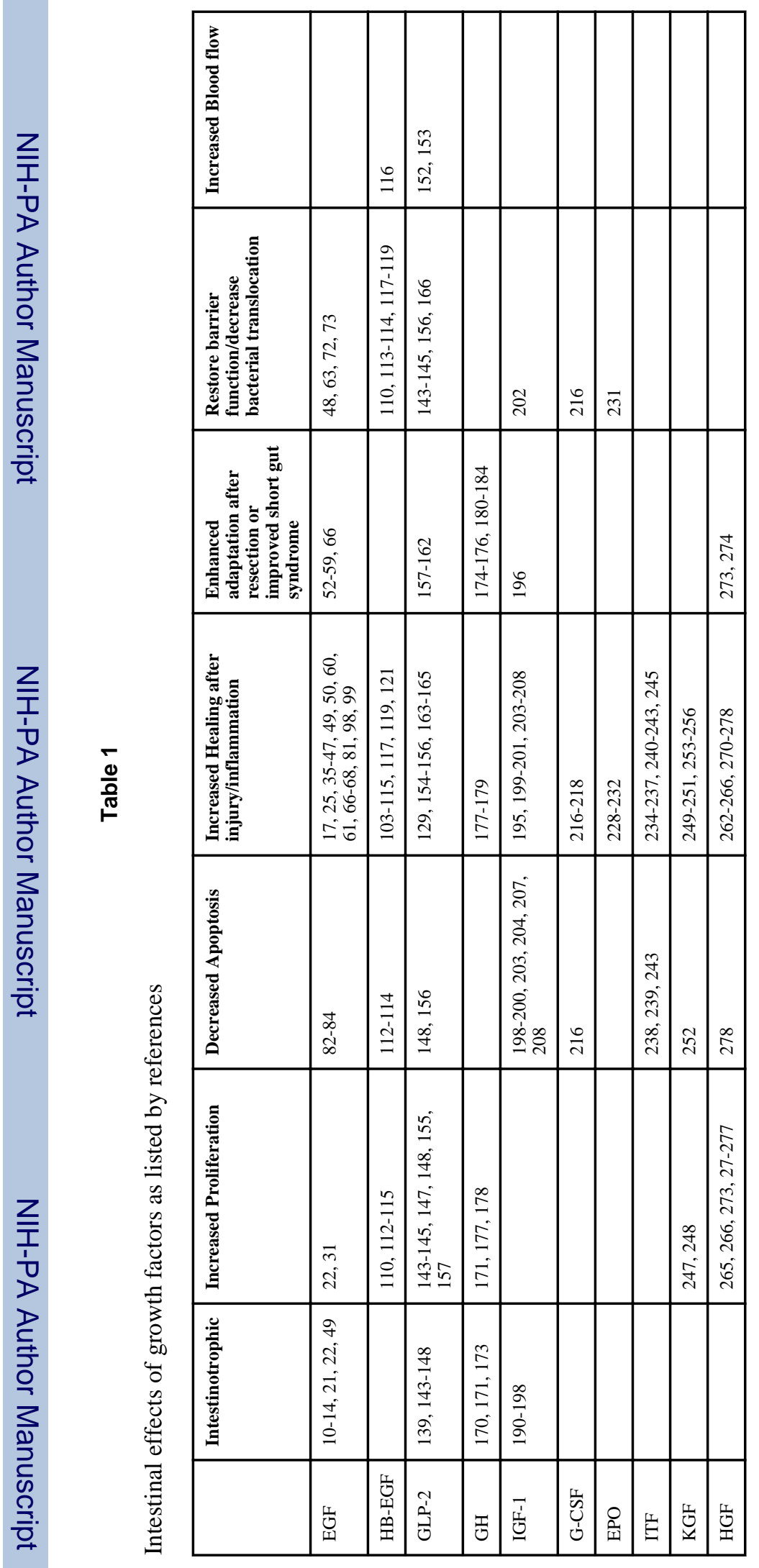

Semin Pediatr Surg. Author manuscript; available in PMC 2014 May 01. 